\title{
Optimum Project Portfolio Selection for Developmental Plans Using Goal Programming
}

\author{
Hameed Al Qaheri, Kuwait University, Kuwait \\ Mohamad Kamal El Din Ahmad Hasan, Kuwait University, Kuwait \\ (iD) https://orcid.org/0000-0003-1185-6034 \\ Mohammad Zainal, Kuwait University, Kuwait
}

\begin{abstract}
In vision-driven development plans, such as the Kuwait Mid-Range Development Plan 2015/20162019/2020, themes and pillars are derived from the plan's vision, and global indices are assigned by international organizations to accurately measure the performance against the vision's themes. This allows for comparison with other countries, and it also set targets for progression over time. One or more projects are assigned to the indicators of these global indices. A multi-criteria mathematical programming technique (e.g., goal programming) is used with multiple goals and priorities where an optimal portfolio of projects is found that satisfied the selection criteria.
\end{abstract}

\section{KEYWORDS}

Evaluation Model, Global Indices, Integer Programming, Kuwait's Mid-Range Development Plan, Multi-Criteria Programming, National Plan, Project Evaluation Model, Project Management, Vision-Driven Development Plans

\section{INTRODUCTION}

The project portfolio selection problem has been discussed for decades by many researchers in the fields of project management, financial management, risk management, and investment (Jafarzadeh et al., 2015; Péreza et al., 2018). It is a complex decision-making process, partially due to the existence of multiple and often conflicting objectives, and partially due to the high number of projects from which a subset or a portfolio is chosen (Khalili-Damghani et al., 2013).

In countries where national development planning is centralized and administered by the state, and where government entities are asked to suggest projects that would lead to the improvement of the of

DOI: 10.4018/IJORIS.20211001.oa1

This article published as an Open Access article distributed under the terms of the Creative Commons Attribution License (http://creativecommons.org/licenses/by/4.0/) which permits unrestricted use, distribution, and production in any medium, provided the author of the original work and original publication source are properly credited. 
the country's position in relation to a set of global indices that would also lead to the improvement of the objectives of the national plan's vision, selecting an optimum portfolio of the suggested projects that would lead to a certain level of improvement in these indices becomes a challenging problem.

In this paper, the project portfolio selection problem is addressed at a national level, within a development planning environment, using Kuwait's Mid-Range Development Plan 2015/2016$2019 / 2020$ as a case. And when dealing with national projects, two sets of activities are identified. There are those that deal the evaluation of each project in terms of their efficiency; effectiveness; broad developmental impact; and sustainability, including cost and benefits analysis, economic analysis, and risk assessment analysis, (etc.). Second, there are those related to the selection of a portfolio of projects to be included in the developmental plan. Figure 1 is a block diagram representing these two sets of activities as a two-stage interrelated process: a project evaluation stage and a project portfolio selection. The focus of this paper is on Stage II, where the output from Stage I, which is the main input to Stage II, is already specified and estimated.

\subsection{The Process of Assigning Project to National Plans}

In vision-driven development plans, such as the one in Kuwait, themes and pillars are derived from the plan's vision. Themes represent desired "end states" for Kuwait, and pillars represent the drivers Kuwait's different institutions (executive, legislative, and judicial) can use to achieve the themes. A matrix of themes by pillars is created, where the intersection of each theme and each pillar (the cell of the matrix) would represent a potential area of improvement. Global indices by international organizations such as the World Bank, the UN, and other international sources are then identified and assigned to each cell of the matrix, that is, the intersection of each theme and pillar, where applicable. These global indices allow for accurately measuring the performance against the vision's themes, allow for comparison with other countries, and set targets for progression over time.

Figure 1. A lock diagram of a two-stage project evaluation and plan's project portfolio selection

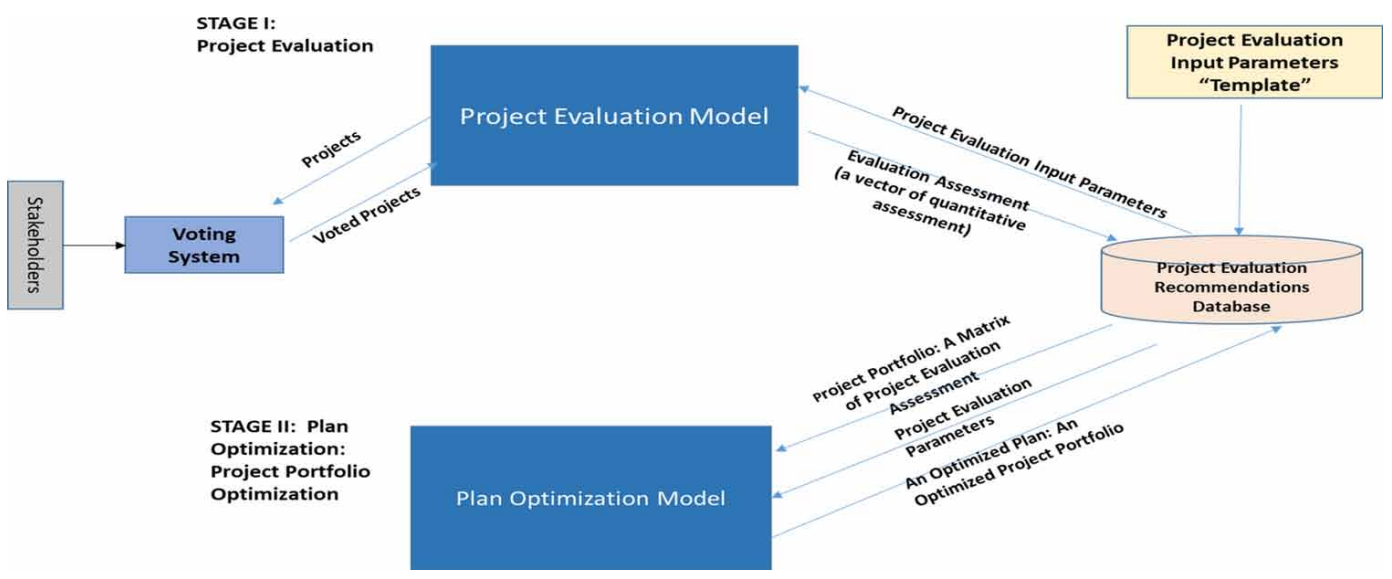

Each global index consists of multiple indicators; each represents a concrete area of improvement. A strategic direction, representing an area of improvement, is specified, and assigned to each indicator, along with a certain targeted position for improvement. Government entities and stakeholders are then asked to use these strategic directions to submit one or more projects for each strategic direction that would address and have an impact on the improvement of the strategic direction. This would consequently lead to the improvement of the indicator to which the strategic direction is assigned. Projects submitted must be directly related to the vision of the development plan. 
In the Kuwait's Mid-Ranged Development Plan, 2015/2016-2019/20, five themes are derived from the vision, and there seven pillars supporting these themes: citizen participation and respect of the law, effective and transparent government, prosperous and diversified economy, nurturing and cohesive nation, and globally relevant and influential player. And the supporting pillars are administration, economy, infrastructure, living environment, healthcare, education and human capital, and international position. Table 1 in the Appendix shows the global indices and their sources, reflecting the position of Kuwait vis-à-vis these indices, indicated as a percentile. Table 2 shows the Themes and Pillar Matrix with global indices.

Vision-related projects are classified into three categories that require different levels of monitoring and support. These three categories are defined as follows:

\section{- Tactical projects}

- Projects that do not frequently occur in Kuwait and have a high measurable impact

- Projects that are not part of the current mandate of the entities but need to happen to achieve Kuwait's vision

- Enabler projects

- Projects that do not have a high measurable impact on a standalone basis but are required in order to support the implementation success of other projects

- Enablers can be infrastructure enablers, which include basic infrastructures such as roads, electricity, water, sewage, and so on, or administrative enablers, such as the improvement of key government processes or the establishment of specialized institutions

- Operational projects

- Projects that occur frequently, or represent a core part of the activities of the government entity that owns the project

According to the above project's classification, The Kuwait's Mid-Ranged Development Plan, 2016/2017-2019/20 includes 17 vision-related tactical projects, 19 enablers, and 88 vision-related operational projects (see Table 3).

To achieve the vision, Kuwait should target to reach a position of at least 30th percentile by 2025 and at least 20th percentile by 2035, globally. These positions would provide Kuwait with a competitive positioning on a regional and international level and would help ensure that Kuwaiti citizens and residents experience a high standard of living.

\section{REVIEW OF LITERATURE}

\subsection{Project Portfolio Selection}

The project portfolio selection (PPS) problem has been discussed by many researchers in the fields of project management, financial management, risk management, and investment for many decades (Baqeri et al., 2019). The project selection is a complex decision-making process, partially due to the existence of multiple and often conflicting objectives, and partially due to the high number of projects from which a subset or a portfolio is chosen.

Tahri (2015) gives the following summary about PPS: “The Project Management Institute (2017) defined the project portfolio as "a set of projects or programs and other operations that are grouped to facilitate effective management of that work in the pursuit of strategic objectives." Thus, the project portfolio is the effective translation of strategic business objectives. Therefore, to successfully manage a project's portfolio, we must choose the projects to be implemented; hence, the projects selection process is so important.

The selection of a project portfolio is a process that involves the evaluation of a set of valid projects that achieve specific strategic objectives (Mantel et al., 2011). This process must be done periodically 
to ensure the selected projects satisfy the organization's resources constraints (Ghasemzadeh \& Archer, 2000) and external constraints (market regulation, laws, and others). This involves solving the problem of project portfolio selection.

To do this, several techniques exist: numeric and non-numeric methods (Mantel et al., 2011) and linear and nonlinear optimization methods for mono-objective and multi-objective problems. Each company must choose the model that best reflects its maturity level (Hugo and Caballero, 2012).

\subsection{Linear Optimization}

In mathematical optimization, a linear optimization (LO) problem is an optimization problem in which we minimize (or maximize) a linear function on a convex polyhedron. Linear functions can describe the function that we minimize (or maximize) and constraints. LO is the discipline that studies these problems; it is also known as linear programming, a term introduced by George Dantzig in 1947, but this name tends to be avoided because of possible confusion with the concept of computer programming.

\subsection{Integer Linear Programming}

Many problems of operational research can be expressed as LO problems. These problems also appear as subproblems in algorithms designed to solve more complex problems. Some LO problems require variables that take only integer values (so-called integrity constraints) or even the values 0 or 1. Then, we are talking about Integer Linear Programming (ILP). These problems are much more challenging to solve than the LO continuous variables. An ILP problem is not an LO problem in the sense that its admissible domain is not a polyhedron but a discrete set of points. However, it can be described as a problem of OL, which adds the additional constraints that some variables can only take integer values. We distinguish between mixed-ILP with integer and continuous variables and the integer problem with all integer variables.

\subsection{Goal Programming}

Goal Programming (GP) is a branch of combinatorial optimization (Wolsey \& Nemhauser, 1999), whose particularity is to try to optimize several objectives simultaneously on the same problem (against a single objective in LO and ILP). The idea for this method was introduced initially by Charnes and Cooper (1961). They presented an approach to solving linear decision problems with multiple objective functions. This method has been extended by Ijiri's (1965) work and Ignizio's (1976) work to solve nonlinear problems. Their method has been used in several theoretical and practical work (Chankong \& Hamies, 1983; Martel \& Aouni, 1998; Spronk, 1981; Steuer, 1985) based on the following assumptions:

- Pre-assign weights (or priorities) to goals or targets groups

- Set values of positive and negative deviations

- Minimize the weighted sum of these deviations

\subsection{Integer Goal Programming}

In the Integer Goal Programming (IGP) method, the same principle applies, except the solution definition domain; we add the additional constraints that the variables can take only integer values or even the two values 0 or 1 , depending on the nature of the problem, in which case it is called 0-1 Goal programming (Tripathy \& Biswal, 2007)". This current research paper used this method.

Recently, Mohagheghi et al. (2019) presented a comprehensive review of project portfolio selection and optimization studies focusing on the evaluation criteria, selection approach, solution approach, uncertainty modeling, and applications. This study reviews more than 140 papers on the project portfolio selection research topic to identify the gaps and present and future trends. The 
findings show that the financial criteria and social and environmental aspects of project portfolios have been foci for research in project portfolio selection in recent years. Also, meta-heuristics and heuristics approaches to finding the solution of mathematical models have been critical research by scholars. For more references see Parth (2017), Budak and Ustundag (2021), and Olson (2017).

\section{PROJECT PORTFOLIO SELECTION OPTIMIZATION}

\subsection{Methodology}

A Multi-Criteria Mathematical Programming Technique (e.g., Goal Programming) is used with multiple goals and priorities to find an Optimal Portfolio of Projects. And given the following model input,

an Optimal Portfolio of Projects is found that satisfies the selection criteria stated below and also that would generate the output specified later in this paper.

\subsubsection{Model Input}

As it was stated earlier, the focus of the paper is on Stage II, the project portfolio selection, and as such, the input to the model would be the output from Stage I. The following parameters are required:

- The project assessments in quantitative values:

- Project is already active or not started yet

- The start and end date for each project

- Project environmental sustainability ranking

- Project financial analysis results (including the annual budget available for each project)

- Project economic analysis results in economic benefits

- Project risk assessment results

- The project type (Tactical project, Enabler project, or Operational project)

- If the project is Enabler, which projects depend on its completion

- The prerequisite projects that are required to be completed before the given project should start

- The contributions of the project to each indicator in term of increasing the percentile of the indicators

- The weight (importance of each index)

- The priority of each index

\subsubsection{Selection Criteria}

1. All active projects that are vision-related will be included in the portfolio automatically. Still, their contributions to the indicators will be added only if they will be completed before the end of March 2025.

2. All Enabler projects will be added if they are a prerequisite for vision-related Tactical or Operational project(s).

3. Tactical projects should take the highest weights and priorities and select a set of these projects with maximum total contributions to their corresponding indicators. The projects with minimum costs and less completion time can be considered to have less weight and priority.

4. Operational projects should take the lowest weights and priorities and select a set of these projects that have maximum total contributions to their corresponding indicators. The projects with minimum costs and less completion time can be considered to have less weight and priority.

5. The annual portfolio costs should not exceed the available annual budget. 


\subsubsection{The Outputs}

1. The Optimal Portfolio of Selected Projects

2. How much did the Optimal Portfolio satisfy the main objective for each of the 19 indices?

3. Which indicators need more future projects and what much room is there for improvement (strategic direction)?

\subsection{Goal Programming Project Portfolio Selection Formulation}

\subsubsection{The Mathematical Model}

In this section, we describe the goal linear programming model that is applied to the portfolio selection of projects submitted with regards to the strategic directions in Kuwait's development plan. An overview of goal linear programming model formulation is given first (see any Operations Research Textbook or Al-Husain et al., 2011; Al-Qaheri \& Hasan, 2010; Al-Qaheri et al., 2011; Hasan et al., 2010; Wu et al., 2017), followed by a detailed description of the specific model related to the application in hand, and finally, input data required for this application are presented.

\subsection{General Goal Linear Programming Model Formulation}

A goal is the desired result. It may be underachieved, fully achieved, or overachieved, and relative emphasis applied through managerial action contributes to the degree of goal achievement. Symbolically, 1 unit of effort applied to activity $x_{j}$ might contribute an amount $a_{i j}$ toward the achievement of the $\mathrm{i}^{\text {th }}$ goal.

The target level for the $\mathrm{i}^{\text {th }}$ goal, $b_{i}$, is fully achieved if

$\sum_{j=1}^{n} a_{i j} x_{j}=b_{i}$

To allow for underachievement or overachievement, let

$d_{i}^{-}=$negative deviation from the $\mathrm{i}^{\text {th }}$ goal (underachievement)

$d_{i}^{+}=$positive deviation from the $\mathrm{i}^{\text {th }}$ goal (overachievement)

From this, for the $\mathrm{i}^{\text {th }}$ can be stated in general terms as

$\sum_{j=1}^{n} a_{i j} x_{j}+d_{i}^{-}-d_{i}^{+}=b i=1,2, \ldots \ldots, m$

It is required that one or both of the deviational variables $\left(d_{i}^{-}, d_{i}^{+}\right)$be zero in the solution since both underachievement and overachievement can't occur at the same time.

The goal programming model must be able to incorporate goal attendants with both ranking and weighting as appropriate. Let

$P_{k}=$ Ranking coefficient for all deviations having $\mathrm{k}^{\text {th }}$ priority of being avoided

$w_{i k}^{-}=$Relative weight of the $d_{i}^{-}$in the $\mathrm{k}^{\text {th }}$ rank

$w_{i k}^{+}=$Relative weight of the $d_{i}^{+}$in the $\mathrm{k}^{\text {th }}$ rank

With $m$ goals, the goal linear programming model may be formulated mathematically as requiring the minimization of the linear weighted ranking function 


$$
\sum_{i=1}^{m} \sum_{k} P_{k}\left(w_{i k}^{-} d_{i}^{-}+w_{i k}^{+} d_{i}^{+}\right)
$$

Subject to the linear constraints

$$
\begin{aligned}
& \sum_{j=1}^{n} a_{i j} x_{j}+d_{i}^{-}-d_{i}^{+}=b_{i} i=1,2, \ldots \ldots, m \\
& x_{j}, d_{i}^{-}, d_{i}^{+} \geq 0 i=1,2, \ldots, m, j=1,2, \ldots, n
\end{aligned}
$$

Goal programming seeks a satisfactory level of goal attainment that represents the best possible overall outcome. This aim can be realized if several goals are stated and formulated mathematically to permit appropriate consideration in the goal programming model. Therefore, the decision-maker must determine which goals are the most important and assign an ordinal value (priority), $P_{k}$, to each goal or group of goals. Further, within a given goal, there may be sub-goals of unequal importance that must be given different weights, $w_{i k}^{-}, w_{i k}^{+}$.

Solving any goal programming model involves achieving the highest priority goal, first, before any of the lower priority goals are considered. Once the highest priority goal is attained to the fullest extent possible, the goal programming model proceeds to find a satisfactory level to the next highest priority goal, and so on. However, it is not always possible to achieve every goal to the extent desired by the decision-maker. But the advantage of goal linear programming over ordinary linear programming is that it seeks, within the given set of constraints, to minimize the deviation from the established goal's targets. In contrast, ordinary linear programming seeks to minimize or maximize certain goals directly.

\subsubsection{Notations}

$c:$ The project category: Enabler $(E)$, Tactical $(T)$ or Operational $(O)$ project

$C$ : The set of all project categories $C=\{E, T, O\}$ i.e. $c \in C$.

$j_{c}:$ Index for project $j$ in category c

$J_{C}$ : The set of all project available to be selected in the portfolio in category c i.e. $j_{c} \in J_{C}$

$J$ : The set of all project available to be selected in the portfolio i.e. $J_{c} \in$

$R_{j_{E}}:$ The set of all projects where the Enabler project $j_{E}$ is a perquisite for them

$i$ : Index for goal $i$ that should test for achievement

$I$ : The set of all goals that should test for achievements i.e. $i \in I$

The starting period in month of project $j_{c}, t_{j_{c}}=1,2, \ldots, f_{j_{c}}$, where $f_{j_{c}}$ is the end period in month of the project $j_{c}$ that does not exceed March 31, 2025

$F_{j_{c}}:$ The set of all $f_{j_{c}}$

$A L$ : The set of all active projects that their $f_{j_{c}}$ does not exceed March 31, 2025

$N A L:$ The total number of AL projects

$A G$ : The set of all active projects that their $f_{j_{c}}$ exceeds March 31, 2025 
$N A G$ : The total number of AG projects

$z_{j_{c}}:$ Global Plan Index for project $j_{c}$

$Z:$ The set of all $z_{j_{c}} Z_{j_{c}}$ to

ycost $_{j_{c} y}$ : The cost of project $j_{c}$ for year $y=1,2, \ldots, 5$

budget $_{y}$ : The total annual budget available for year $y=1,2, \ldots, 5$

$y_{z_{j_{c}}}$ : Index of project indicator $y$ that belong to project index $z_{j_{c}}$

$Y_{z_{j_{\kappa}}}$ : The set of all $y_{z_{j_{c}}}$

$b_{z_{z_{j_{c}}}}$ : The contributions for the project $j_{c}$ to each indicator $y_{z_{j_{c}}}$ : in terms of increasing the percentile of the indicators

$d_{i}^{-}=$Negative deviation from the $i^{\text {th }}$ goal (underachievement)

$d_{i}^{+}=$Positive deviation from the $i^{\text {th }}$ goal (overachievement)

$k=$ Index for priority

$P_{k}=$ Ranking coefficient for all deviations having $k^{\text {th }}$ priority of being avoided

$w_{i k}^{-}=$Relative weight of the $d_{i}^{-}$in the $k^{\text {th }}$ rank

$w_{i k}^{+}=$Relative weight of the $d_{i}^{+}$in the $k^{\text {th }}$ rank

The decision variables:

$X_{j_{c} y_{z_{c}} t_{j_{c}}}=1$ If project $j$ of category $c$ that have indicator $y_{z_{j}}$ and start at time $t_{j}$ is selected to be in the portfolio

$X_{j c y_{z_{j_{c}}} t_{j_{c}}}=0$ Otherwise

\subsubsection{Goal 1}

All active projects that are vision-related will be included in the portfolio automatically. Still, their contributions to the indicators will be added only if they will be completed before the end of March 2025. This has a priority ,

$$
X_{j c y_{z_{j} j i c}}+d_{1}^{-}-d_{1}^{+}=1 \forall j_{c} \in A \text { Landc } \in C
$$

and the objective is to minimize both of $d_{1}^{-}$and $d_{1}^{+}$.

\subsubsection{Goal 2}

All Enabler projects will be added in the portfolio if they are a prerequisite for vision-related Tactical or Operational project(s). This has a priority $P_{1}$,

$$
X_{j_{E} y_{z_{E}} t_{j_{E}}}+d_{2}^{-}-d_{2}^{+}=1 \forall j_{E} \text { where } R_{j_{E}} \neq \varnothing
$$

$\mathrm{d}$ the objective is to minimize both of $d_{2}^{-}$and $d_{2}^{+}$. 


\subsubsection{Goal 3}

Tactical projects should take the highest weights and priorities and select a set of these projects with maximum total contributions to their corresponding indicators. This has a priority $P_{2}$,

$\Sigma c \in T b_{y z z_{j c}} X_{j c y z^{j c}}+d_{3}^{-}-d_{3}^{+}=M_{1}$

where $M_{1}$ should exceed the maximum total contributions of tactical projects to their corresponding indicators, and the objective is to minimize $d_{3}^{-}$with $w_{32}^{-}$taking the highest weight.

\subsubsection{Goal 4}

Tactical projects with minimum costs for these projects can be considered to have less weight and priority. This has a priority $P_{3}$

$\Sigma y E c \in T^{y \cos t} j c y X_{j c y z}{ }_{j c}^{t j c}+d_{4}^{-}-d_{4}^{+}=M_{2}$

where $M_{2}$ should not exceed the maximum total costs of tactical projects, and the objective is to minimize $d_{4}^{+}$with $w_{43}^{+}<w_{32}^{-}$.

\subsubsection{Goal 5}

Tactical projects with less completion time for these projects can be considered to have less weight and priority. This has a priority $P_{4}$,

$\Sigma c \in T f_{j c} X_{j c y z^{j c}}+d_{5}^{-}-d_{5}^{+}=M_{3}$

where $M_{3}$ should not exceed the maximum total completion times of tactical projects, and the objective is to minimize $d_{5}^{+}$with $w_{54}^{+}<w_{43}^{+}$.

\subsubsection{Goal 6}

Operational projects should take the highest weight and priority and select a set of these projects that have maximum total contributions to their corresponding indicators. This has a priority $P_{5}$,

$\Sigma c \in o b_{y z} X_{j c y z^{j c}}+d_{6}^{-}-d_{6}^{+}=M_{4}$

where $M_{4}$ should exceed the maximum total contributions of operational projects to their corresponding indicators, and the objective is to minimize $d_{6}^{-}$with $w_{65}^{-}<w_{54}^{+}$taking the highest weight.

\subsubsection{Goal 7}

Operational projects with minimum costs for these projects can be considered to have less weight and priority. This has a priority $P_{6}$, 
$\Sigma y \Sigma c \in o^{y \cos t_{j c y}} X_{j c y z^{j c}}+d_{7}^{-}-d_{7}^{+}=M_{5}$

where $M_{5}$ should not exceed the maximum total costs of operational projects, and the objective is to minimize $d_{7}^{+}$with $w_{76}^{+}<w_{65}^{-}$.

\subsubsection{Goal 8}

Operational projects with less completion time for these projects can be considered to have less weight and priority. This has a priority $P_{7}$,

$\sum_{c \in T} f_{j_{c}} X_{j_{c} y_{z_{c}} t_{j_{c}}}+d_{8}^{-}-d_{8}^{+}=M_{6}$

where $M_{6}$ should not exceed the maximum total completion times of operational projects, and the objective is to minimize $d_{8}^{+}$with $w_{87}^{+}<w_{76}^{+}$.

\subsubsection{Goal 9}

The annual portfolio costs should not exceed the total annual available budget for each year. This has a priority $P_{8}$, and the objective is to minimize $d_{8+y}^{+}$.

$\sum_{j_{c}}\left(\right.$ ycost $_{j_{c} y}-$ budget $\left._{y}\right) X_{j_{c} y_{z_{c}} t_{j_{c}}}-d_{8+y}^{+}=0$ for $y=1,2,3,4,5$

\subsubsection{Goal 10}

The selected projects portfolio should reduce the average of the Global Indices to 30 by the end of year 2020 .

$\frac{\sum z_{j c} \in z \Sigma y z_{j c} \in z_{j c} b y z_{j c} X j c y z_{j c} t_{j c}}{|z|}+d^{-}{ }_{14}-d^{+}{ }_{14}=30$

This has a priority $P_{9}$ and the objective is to minimize $d_{14}^{+}$.

\subsubsection{The Goal Programming (GP) Model}

Minimize $P_{1}\left(d_{1}^{-}+d_{1}^{+}+d_{2}^{-}+d_{2}^{+}\right)+P_{2} w_{32}^{-} d_{3}^{-}+P_{3} w_{43}^{+} d_{4}^{+}+P_{4} w_{54}^{+} d_{5}^{+}+P_{5} w_{65}^{-} d_{6}^{-}+P_{6} w_{76}^{+} d_{7}^{+}+P_{7} w_{87}^{+} d_{8}^{+}+P_{8} \sum_{y=1}^{y=5} d_{8+y}^{+}$

$+P_{9} d_{14}^{+}$

subject to:

$X_{j_{c} y_{z_{j_{c}}} t_{j_{c}}}+d_{1}^{-}-d_{1}^{+}=1 \forall j_{c} \in A L$ and $c \in C$

$X_{j_{E} y_{z_{j_{E}}} t_{j_{E}}}+d_{2}^{-}-d_{2}^{+}=1 \forall j_{E}$ where $R_{j_{E}} \neq \varnothing$ 


$$
\begin{aligned}
& \sum_{c \in T}^{b} b_{y_{z_{c}}} X_{j_{c} y_{z_{j_{c}}} t_{j_{c}}}+d_{3}^{-}-d_{3}^{+}=M_{1} \\
& \sum_{y} \sum_{c \in T} y \operatorname{cost}{j_{j_{c} y}}_{j_{j_{c} y_{z_{c}} t_{j_{c}}}}+d_{4}^{-}-d_{4}^{+}=M_{2} \\
& \sum_{c \in T} f_{j_{c}} X_{j_{c} y_{z_{c}} t_{j_{c}}}+d_{5}^{-}-d_{5}^{+}=M_{3} \\
& \sum_{c \in O} b_{y_{z_{j_{c}}}} X_{j_{c} y_{z_{j_{c}}} t_{j_{c}}}+d_{6}^{-}-d_{6}^{+}=M_{4} \\
& \sum_{y} \sum_{c \in O} y \operatorname{cost} t_{j_{c} y} X_{j_{c} y_{z_{c}} t_{j_{c}}}+d_{7}^{-}-d_{7}^{+}=M_{5} \\
& \sum_{c \in T} f_{j_{c}} X_{j_{c} y_{z_{c}} t_{j_{c}}}+d_{8}^{-}-d_{8}^{+}=M_{6} \\
& \sum_{j_{c}}\left(y \operatorname{cost} t_{j_{c} y}-\text { budget } t_{y}\right) X_{j_{c} y_{z_{c}} t_{j_{c}}}-d_{8+y}^{+}=0 \text { for } y=1,2,3,4,5 \\
& \frac{\sum_{z_{j_{c} \in Z}} \sum_{y_{z_{j_{c}} \in z_{j_{c}}}} b_{y_{z_{j_{c}}}} X_{j_{c} y_{z_{j_{c}}} t_{j_{c}}}}{|Z|}+d_{14}^{-}-d_{14}^{+}=30 \\
& X_{j_{c} y_{z_{j_{c}}} t_{j_{c}}}=\left\{\begin{array}{l}
1 \\
0
\end{array} \forall j_{c}\right. \\
& d_{i}^{-}, d_{i}^{+} \geq 0 \text { for } i=1,2, \ldots, 14
\end{aligned}
$$

\section{INPUT DATA AND MODEL DEVELOPMENT}

An Excel file was developed from all data input included in the Kuwait Mid-Range Development Plan 2015/2016-2019/2020. And to test the previous Binary Mixed Goal Programming Model (BMGPM), we assumed values for all the model requirements. We ran the model in two ways. First, the model was run using an Excel built-in Frontline Solver, which requires an Excel datasheet. Then we developed another representation of the model using Frontline RASON, a high-level, declarative modeling language embedded in JSON (JavaScript Object Notation), the popular structured format widely used in Web and mobile applications. This representation does not require input from an Excel datasheet but inputs data from any source, such as a text data file, data from a database, and data from an Excel datasheet.

\section{MODEL RESULTS AND ANALYSIS}

Factitious data were used to validate the model to understand that when real data are available the model should provide valid results. Both model representations, the Excel-based and the RASON formulation mentioned above, and their solvers, generated identical results. And the generated results satisfied all the goals of the model and produced an optimum portfolio of projects.

Table 3 in the Appendix shows all the projects and key information represented as columns in the table. For example, a value of 1 in the Project Selection column indicates that the project is selected in 
the portfolio, and 0 means the project is not selected. The table shows that the best portfolio includes the following projects:

a) Tactical projects: 9 projects (projects IDs T3, T4, T6, T8, T9-T12, and T15) are selected out of a total of 17 Tactical projects.

b) Enabler projects: All the 19 Enabler projects are selected.

c) Operational projects: 64 projects (O1-O64) are selected out of a total of 88 Operational projects.

The total project portfolio contributions (decrease percentile) is 6.42 .

Table 4 in the Appendix shows that Goal 1 and Goal 2 are satisfied for selected projects where all $d_{1}^{-}, d_{1}^{+}$and $d_{2}^{-}, d_{2}^{+}$are equal to zeros, as we want them to be minimized, and their priority $P_{1}$ is satisfied in Table 7.

Table 5 shows Goals 3 to 8 are satisfied, as they stated in the model description where the level is the value of the left-hand side (LHS) of the goal (the part before the negative and/or positive deviations). The Project Goal is the right-hand side (RHS) of the goal. All the positive or negative deviations that should be minimized are equal to zero, and the values of the weights for the goals are $w_{32}^{-}=100, w_{43}^{+}=80, w_{54}^{+}=70, w_{65}^{-}=60, w_{76}^{+}=50$, and $w_{87}^{+}=40$, which satisfied the conditions: $w_{32}^{-}$take highest weight for goal 3, $w_{43}^{+}<w_{32}^{-}$for goal $4, w_{54}^{+}<w_{43}^{+}$for goal 5, $w_{65}^{-}<w_{54}^{+}$for goal $6, w_{76}^{+}<w_{65}^{-}$for goal 7, and $w_{87}^{+}<w_{76}^{+}$for goal 8 . The priority $P_{2}-P_{7}$ is for Goals 3 through 8 are satisfied in Table 7.

Table 6 in the Appendix shows that Goal 9 for years 1-5 are all satisfied where the positive deviations (amount over) are all zeros. It is to be noted that level $=0$, in year 1 , means that the total cost equals to the total budget for this year (which is true) and their priority $P_{8}$ is satisfied in Table 7 .

Table 6 also shows the result of Goal 10 and their priority $P_{9}$ is not satisfied and have a value of 2.1 (as shown in Table 7) percentile as over deviation $d_{14}^{+}$that should be zero in the objective function.

Table 9 shows the average of the Global Indices is 51.39 and the average of the contribution to index improvement is 32.1 excluding indices 4 and 18 as no projects were assigned to these two indices.

It must also be emphasized that this index improvement is for 2020 and not for 2025 as the situation for the next 5-year plan (2021-2025) would be different in terms of assigning projects to the Global Indices.

Table 7 shows that all priorities $P_{1}-P_{8}$ are satisfied with the total value of the objective function is equal to zero for $P_{9}$ ( $P_{9}=2.1$ which means that this goal is not satisfied as mentioned above).

Table 8 in the Appendix shows each index, the projects assigned to it, project code, project selection status ( 1 selected, 0 not selected), and the improvement (project percentile improvement). The totals for each index are also shown. For example, for Index 1 there are 4 projects, 3 projects, and the total improvement to the index percentile is 15 . It should be clarified, as it was indicated at the beginning of the paper, that each index consists of multiple indicators and projects are assigned to one or more indicators of the index. So, in reality, the percentile improvement of each project is an improvement of the indicator's percentile. The average improved percentile of all indicators of the index becomes the improved percentile of the index.

Table 9 summarizes and provides extra information as follows:

1. The Contribution to Index Improvement means the total project portfolio contribution to the index. 
2. The Percentage of Improvement is the Contribution to Index Improvement divided by the Index Percentile.

3. The New Percentile is generated by subtracting the Contribution to Index Improvement from the Index Percentile.

4. The improvement Required per Plan is generated by dividing 20 by 4 . The 20 refers to the percentage needed to improve the global indices by 2035 (the end of the $4^{\text {th }}$ development plan), and the 4 refers to the number of plans (during the period 2015 to 2035). And the average for the 4 plans during this period is 5 percent.

5. The Average Per Plan is generated by dividing improvement Required per Plan by the Index Percentile.

6. Over/Under Achievement is computed by subtracting the Avg Per Plan from the Percentage of Improvement.

So, for example, Index 1's percentile is 40, 4 projects were assigned to this index, and only 3 were selected. The total improvement of the selected projects is 15 , a $38 \%$ improvement, which leads to a new index percentile of 25 , an improvement of 15 points, which is 10 points improvement over the required 5 points. The objective is to improve this index by 5 , however, for the selected project portfolio does not include projects for two of the indices, 4 and 18, as projects were not assigned to these.

Table 10 shows the fictitious cost and budget available data for goals 4, 6, 7, and 9.

\section{CONCLUSION AND FUTURE RESEARCH}

In vision-driven development plans, such as the Kuwait Mid-Range Development Plan 2015/20162019/2020, themes and pillars are derived from the plan's vision, and global indices by international organizations are assigned by international organizations to accurately measure the performance against the vision's themes. This allows for comparison with other countries and also set targets for progression over time. One or more projects are assigned to the indicators of these global indices. A Multi-Criteria Mathematical Programming Technique (e.g., Goal Programing) is used, with multiple goals and priorities, where an Optimal Portfolio of Projects is found that satisfied the selection criteria. Two models were developed using an Excel built-in Frontline Solver and Frontline RASON, a highlevel, declarative modeling language. The models were tested using fictitious data. Both models generated identical optimum projects portfolios that lead to the significant improvement of the global indices the projects were assigned to.

As a complementary project to this paper, future research would be to implement Stage I (as shown in Figure 1 above) and create a system that integrates Stage I and II. And another future research project would be to create a Decision Support System (DSS), encoding Frontline RASON code for testing and validating different scenarios using real data. Another future research is to create a Plan Simulator to explore the impact of the selected projects on the Global Indices of the 5-year plan before the plan approval and its actual implementation. 


\section{REFERENCES}

Al-Husain, R., Hasan, M. K., \& Al-Qaheri, H. (2011). A sequential three-stage Integer Goal Programming (IGP) Model for faculty-course-time-classroom assignments. Informatica (Vilnius), 35, 157-164.

Al-Qaheri, H., \& Hasan, M. K. (2010). An end-user decision support system for portfolio selection: A goal programming approach with an application to Kuwait Stock Exchange. International Journal of Computer Information Systems and Industrial Management Application, 2, 1-10.

Al-Qaheri, H., Hasan, M. K., \& Al-Husain, R. (2011). A decision support system for a three-stage university course scheduler with an application to College of Business Administration, Kuwait University. International Journal of Data Analysis and Information Systems, 3(2), 95-110.

Baqeri, K., Mohammadi, E., \& Gilan, N. (2019). Multi objective project portfolio selection. Journal of Project Management, 4(4), 249-256. doi:10.5267/j.jpm.2019.6.003

Budak, A., \& Ustundag, A. (2021). Technology Project Portfolio Selection in Industry 4.0. In I. Management Association (Ed.), Research Anthology on Cross-Industry Challenges of Industry 4.0 (pp. 877-894). IGI Global. doi:10.4018/978-1-7998-8548-1.ch044

Chankong, V., \& Hamies, Y. Y. (1983). Multiobjective decision making: Theory and methodology. ElsevierNorth-Holland.

Charnes, A., \& Cooper, W. W. (1961). Management models and industrial applications of linear programming. John Wiley.

Ghasemzadeh, F., \& Archer, N. P. (2000). Project portfolio selection through decision support. Decision Support Systems, 29(1), 73-88. doi:10.1016/S0167-9236(00)00065-8

Hasan, M. K., Hussain, R., \& Al-Qaheri, H. (2010). A sequential two-stage goal programming model for facultycourse-time slot assignments. Arab Journal of Administrative Sciences, 17(1), 169-191.

Hugo, C., \& Caballero, S. (2012). Project portfolio selection using mathematical programming and optimization methods. 2012 PMI Global Congress Proceedings, Vancouver, Canada.

Ignizio, J. P. (1976). Goal programming and its extensions. D.C. Heath.

Ijiri, J. (1965). Management goals and accounting for control. American Elsevier.

Jafarzadeh, M., Tareghian, H. R., Rahbarnia, F., \& Ghanbari, R. (2015). Optimal selection of project portfolios using reinvestment strategy within a flexible time horizon. European Journal of Operational Research, 243(2), 658-664. doi:10.1016/j.ejor.2014.12.013

Khalili-Damghani, K., Sadi-Nezhad, S., Hosseinzadeh Lotf, F., \& Tavana, M. (2013). A hybrid fuzzy rulebased multi-criteria framework for sustainable project portfolio selection. Information Sciences, 220, 442-462. doi:10.1016/j.ins.2012.07.024

Kuwait Mid-Range Development Plan -2015/2016 - 2019/2020 Working Draft. (2015). https://andp.unescwa. org/sites/default/files/2020-09/Kuwait\%20National\%20Mid-range\%20Development\%20Plan\%2020152016\%20 -\%2020192020.pdf

Mantel, S. J., Meredith, J. R., Shafer, S. M., \& Sutton, M. M. (2011). Project management in practice. John Wiley \& Sons.

Martel, J. M., \& Aouni, B. (1998). Diverse imprecise goal programming model formulations. Journal of Global Optimization, 12127-12138.

Mohagheghi, V., Mousavi, S., Antuchevičienė, J., \& Mohammad Mojtahedi, M. (2019). Project portfolio selection problems: A review of models, uncertainty approaches, solution techniques, and case studies. Technological and Economic Development of Economy, 25(6), 1380-1412. doi:10.3846/tede.2019.11410

Olson, B. (2017). Optimizing Portfolio Value through Comprehensive Project Metrics. In L. Romano (Ed.), Project Portfolio Management Strategies for Effective Organizational Operations (pp. 178-201). IGI Global. doi:10.4018/978-1-5225-2151-8.ch007 
Parth, F. R. (2017). Project Portfolio Management Growth and Operation: Portfolio Management Structure, Operations, Risk, and Growth. In L. Romano (Ed.), Project Portfolio Management Strategies for Effective Organizational Operations (pp. 264-287). IGI Global., doi:10.4018/978-1-5225-2151-8.ch011

Péreza, F., Gómezb, T., Caballerob, R., \& Liernc, V. (2018). Project portfolio selection and planning with fuzzy constraints. Technological Forecasting and Social Change, 131, 117-129. doi:10.1016/j.techfore.2017.07.012

Spronk, J. (1981). Interactive multiple goal programming: Applications to financial planning. Martinius Nijhoff Publishing. doi:10.1007/978-94-009-8165-2

Steuer, R. E. (1985). Multiple criteria optimization: Theory, computation and applications. John Wiley and Sons.

Tahri, H. (2015). Mathematical Optimization Methods: Application in Project Portfolio Management. Procedia: Social and Behavioral Sciences, 210, 339-347. doi:10.1016/j.sbspro.2015.11.374

The Project Management Institute. (2017). A guide to the project management body of knowledge (PMBOK Guide) (4th ed.). Project Management Institute, Inc.

Tripathy, B. B., \& Biswal, M. P. (2007). A zero-one goal programming approach for project selection. Journal of Information \& Optimization Sciences, 28(4), 619-626. doi:10.1080/02522667.2007.10699763

Wolsey, A. L., \& Nemhauser, G. L. (1999). Integer and combinatorial optimization. Wiley.

Wu, S., Toussaint, J., \& Messer, K. D. (2017). Maximizing benefits in project selection: A hybrid approach. Applied Economics, 49(40), 4071-4082. doi:10.1080/00036846.2016.1276267 


\section{APPENDIX}

\section{Table 1. Global indices}

\begin{tabular}{|c|c|c|c|}
\hline \# & Index & $\begin{array}{l}\text { Current } \\
\text { Percentile }\end{array}$ & Source \\
\hline 1 & Ethical government index * & 40 & World Economic Forum “Global Competitiveness Report”, 2014-15 \\
\hline 2 & Effective policymaking index* & 61 & World Economic Forum "Global Competitiveness Report", 2014-15 \\
\hline 3 & Ease of doing business index & 51 & World Bank, 2014 \\
\hline 4 & Government spending index* & 55 & $\begin{array}{l}\text { World Bank, 2011-2013 Business Monitor International, 2011-2014 } \\
\text { Economic and social commission for Western Asia "National accounts } \\
\text { studies of the Arab region" report, } 2013\end{array}$ \\
\hline 5 & Business sophistication index & 53 & World Economic Forum "Global Competitiveness Report", 2014-15 \\
\hline 6 & Labor market performance index* & 40 & $\begin{array}{l}\text { World Economic Forum "Global Competitiveness Report", 2014-15 United } \\
\text { Nations Development Program, } 2013\end{array}$ \\
\hline 7 & Exports of goods \& services index* & 49 & United Nations conference on Trade and Development (UNCTAD), 2013-14 \\
\hline 8 & Government ICT usage index* & 67 & World Economic Forum “Global Information Technology Report", 2014 \\
\hline 9 & Logistics performance index & 38 & World Bank "Logistics Performance Index report", 2014 \\
\hline 10 & Quality of transport infrastructure* & 53 & World Economic Forum "Global Competitiveness Report", 2014-15 \\
\hline 11 & Cross-border traffic flow index & 49 & World Bank, 2013-14 \\
\hline 12 & Resource \& energy use index* & 78 & $\begin{array}{l}\text { World oil and gas review, 2014; World Bank, 2010-13; International Energy } \\
\text { statistics, } 2012\end{array}$ \\
\hline 13 & $\begin{array}{l}\text { Average time to obtain public } \\
\text { housing }\end{array}$ & 20 years & Public Authority for Housing Welfare, to be internally calculated \\
\hline 14 & Environment performance index & 43 & $\begin{array}{l}\text { Environment Performance Index, } 2014 \text { (Yale Center for Environmental Law } \\
\text { \& Policy) }\end{array}$ \\
\hline 15 & Healthcare quality index* & 54 & $\begin{array}{l}\text { International Diabetes Federation, Atlas 6th edition (2014 update) World } \\
\text { Economic Forum "Global Competitiveness Report", 2014-15 World Health } \\
\text { Organization "Globocan Report", } 2012\end{array}$ \\
\hline 16 & Workforce readiness index* & 65 & $\begin{array}{l}\text { World Economic Forum "Global Competitiveness Report", 2014-15 World } \\
\text { Economic Forum "Human Capital Report", 2014-15 }\end{array}$ \\
\hline 17 & Education quality index* & 69 & World Economic Forum "Global Competitiveness Report", 2014-15 \\
\hline 18 & Global peace index & 17 & Institute for Economics and Peace, 2014 \\
\hline 19 & Net inflows of FDIs* & 36 & World Bank, 2013 \\
\hline 20 & International relations index* & 59 & $\begin{array}{l}\text { Henley \& Partners, } 2014 \text { Bloom Consulting "Country Brand Ranking } \\
\text { Report", 2014-15 }\end{array}$ \\
\hline
\end{tabular}

${ }^{*}$ Composite indices calculated as a composition of various indicators based on international sources. 
Table 2. The themes and pillars matrix and the global indices

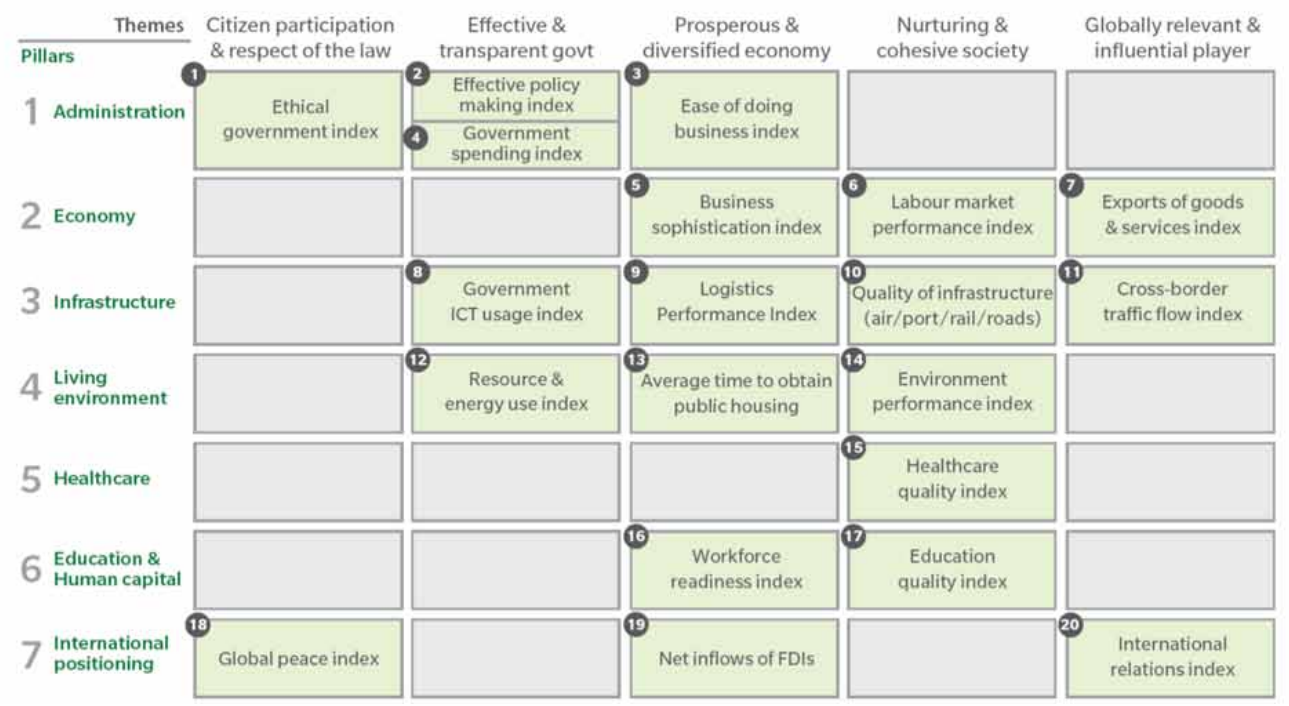

Source: Kuwait Mid-Range Development Plan -2015/2016-2019/2020 Working Draft, https://www.scpd.gov.kw/archive/20150708\%20Revamped\%20 KDP_PDF\%20version_EN.pdf 
Table 3. The projects selection

\begin{tabular}{|c|c|c|c|c|c|c|}
\hline \multirow[t]{2}{*}{ Project } & \multirow[t]{2}{*}{$\begin{array}{l}\text { Project } \\
\text { Code }\end{array}$} & \multirow[t]{2}{*}{ Name } & \multirow{2}{*}{$\begin{array}{c}\begin{array}{c}\text { Project } \\
\text { Type }\end{array} \\
(\mathrm{E}, \mathrm{T}, \mathrm{O})\end{array}$} & \multirow[t]{2}{*}{$\begin{array}{c}\text { Project } \\
\text { Selection }\end{array}$} & \multirow[t]{2}{*}{$\begin{array}{l}\text { Total Project } \\
\text { Contributions }\end{array}$} & \multirow[t]{2}{*}{$\begin{array}{c}\text { Portfolio } \\
\text { Contributions }\end{array}$} \\
\hline & & & & & & \\
\hline 1 & $\mathrm{~T} 1$ & Revamp of coop societies system & $\mathrm{T}$ & 0 & 1 & 0 \\
\hline 2 & $\mathrm{~T} 2$ & $\begin{array}{l}\text { Create an incubator for small and medium } \\
\text { enterprises }\end{array}$ & $\mathrm{T}$ & 0 & 5 & 0 \\
\hline 3 & $\mathrm{~T} 3$ & $\begin{array}{l}\text { Develop Boubyan Island and Silk City } \\
\text { (consultancy study only) }\end{array}$ & $\mathrm{T}$ & 1 & 5 & 5 \\
\hline 4 & $\mathrm{~T} 4$ & $\begin{array}{l}\text { Expansion in the creation and development of free } \\
\text { zones in Kuwait }\end{array}$ & $\mathrm{T}$ & 1 & 2 & 2 \\
\hline 5 & T5 & Unions cities project - 6 cities & $\mathrm{T}$ & 0 & 6 & 0 \\
\hline 6 & T6 & $\begin{array}{l}\text { Public warehouses and border crossings company } \\
\text { (Abdali) }\end{array}$ & $\mathrm{T}$ & 1 & 3 & 3 \\
\hline 7 & $\mathrm{~T} 7$ & Design and implement the e-Kuwait project & $\mathrm{T}$ & 1 & 10 & 10 \\
\hline 8 & $\mathrm{~T} 8$ & Railway project & $\mathrm{T}$ & 1 & 4 & 4 \\
\hline 9 & T9 & Metro project & $\mathrm{T}$ & 1 & 2 & 2 \\
\hline 10 & $\mathrm{~T} 10$ & Mubarak Al-Kabeer port & $\mathrm{T}$ & 1 & 8 & 8 \\
\hline 11 & $\mathrm{~T} 11$ & $\begin{array}{l}\text { Enriching local fisheries through information } \\
\text { management and developing techniques }\end{array}$ & $\mathrm{T}$ & 1 & 6 & 6 \\
\hline 12 & $\mathrm{~T} 12$ & Hospitals health insurance company & $\mathrm{T}$ & 1 & 8 & 8 \\
\hline 13 & $\mathrm{~T} 13$ & $\begin{array}{l}\text { Develop and implement a training program for } \\
\text { Kuwaiti professionals }\end{array}$ & $\mathrm{T}$ & 1 & 15 & 15 \\
\hline 14 & $\mathrm{~T} 14$ & $\begin{array}{l}\text { Establishment of the national employment } \\
\text { development center }\end{array}$ & $\mathrm{T}$ & 0 & 5 & 0 \\
\hline 15 & $\mathrm{~T} 15$ & Sabah Al-Salem University project & $\mathrm{T}$ & 1 & 2 & 2 \\
\hline 16 & $\mathrm{~T} 16$ & $\begin{array}{l}\text { Determine the work of disciplines offered by } \\
\text { private universities and colleges market needs }\end{array}$ & $\mathrm{T}$ & 0 & 8 & 0 \\
\hline 17 & $\mathrm{~T} 17$ & $\begin{array}{l}\text { Improve standards for learning in Kuwait for } \\
\text { teachers, curricula, and management }\end{array}$ & $\mathrm{T}$ & 1 & 7 & 7 \\
\hline 18 & E1 & Reform of the financial management of the state & $\mathrm{E}$ & 1 & 4 & 4 \\
\hline 19 & E2 & $\begin{array}{l}\text { Strategy preparation of a national integrity, } \\
\text { transparency, and anti-corruption strategy }\end{array}$ & $\mathrm{E}$ & 1 & 6 & 6 \\
\hline 20 & E3 & $\begin{array}{l}\text { Activating and developing legislative frameworks } \\
\text { and institutional mechanisms in line with } \\
\text { international conventions }\end{array}$ & $\mathrm{E}$ & 1 & 9 & 9 \\
\hline 21 & E4 & North Zour station - phase ii & $\mathrm{E}$ & 1 & 8 & 8 \\
\hline 22 & E5 & $\begin{array}{l}\text { Al-Khairan power station and water distillation } \\
\text { plant - phase i }\end{array}$ & $\mathrm{E}$ & 1 & 5 & 5 \\
\hline 23 & E6 & $\begin{array}{l}\text { Establishment and operation power generation } \\
\text { plants (Abdaliyah) }\end{array}$ & $\mathrm{E}$ & 1 & 3 & 3 \\
\hline 24 & E7 & $\begin{array}{l}\text { Establish mechanisms to maintain the rights of } \\
\text { migrant workers }\end{array}$ & $\mathrm{E}$ & 1 & 3 & 3 \\
\hline 25 & E8 & $\begin{array}{l}\text { Create organization communications and } \\
\text { information technology commission }\end{array}$ & $\mathrm{E}$ & 1 & 7 & 7 \\
\hline 26 & E9 & Create transport regulatory authority & E & 1 & 5 & 5 \\
\hline 27 & E10 & Improve roads infrastructure & $\mathrm{E}$ & 1 & 4 & 4 \\
\hline 28 & E11 & Implementation of the master plan of the state & $\mathrm{E}$ & 1 & 6 & 6 \\
\hline
\end{tabular}


Table 3. Continued

\begin{tabular}{|c|c|c|c|c|c|c|}
\hline \multirow[t]{2}{*}{ Project } & \multirow[t]{2}{*}{$\begin{array}{l}\text { Project } \\
\text { Code }\end{array}$} & \multirow[t]{2}{*}{ Name } & $\begin{array}{l}\text { Project } \\
\text { Type }\end{array}$ & \multirow[t]{2}{*}{$\begin{array}{l}\text { Project } \\
\text { Selection }\end{array}$} & \multirow[t]{2}{*}{$\begin{array}{l}\text { Total Project } \\
\text { Contributions }\end{array}$} & \multirow[t]{2}{*}{$\begin{array}{c}\text { Portfolio } \\
\text { Contributions }\end{array}$} \\
\hline & & & $(\mathbf{E}, \mathbf{T}, \mathbf{O})$ & & & \\
\hline 29 & E12 & Healthy cities initiative & $\mathrm{E}$ & 1 & 6 & 6 \\
\hline 30 & E13 & Health promotion & $\mathrm{E}$ & 1 & 4 & 4 \\
\hline 31 & E14 & $\begin{array}{l}\text { Measuring patient satisfaction and dealing with the } \\
\text { health services }\end{array}$ & $\mathrm{E}$ & 1 & 1 & 1 \\
\hline 32 & E15 & $\begin{array}{l}\text { Change concepts and values of work in the private } \\
\text { sector }\end{array}$ & $\mathrm{E}$ & 1 & 6 & 6 \\
\hline 33 & E16 & $\begin{array}{l}\text { Study "mesa advantage" to measure and evaluate } \\
\text { the education system }\end{array}$ & $\mathrm{E}$ & 1 & 5 & 5 \\
\hline 34 & E17 & Linking embassies to issue a visa from abroad & $\mathrm{E}$ & 1 & 6 & 6 \\
\hline 35 & E18 & $\begin{array}{l}\text { Enforce legislative requirements of vision and } \\
\text { development plan }\end{array}$ & $\mathrm{E}$ & 1 & 1 & 1 \\
\hline 36 & E19 & $\begin{array}{l}\text { Building integrated legislative framework for } \\
\text { environmental management }\end{array}$ & E & 1 & 1 & 1 \\
\hline 37 & O1 & $\begin{array}{l}\text { Adoption and implementation of sound corporate } \\
\text { governance standards by the units of the banking } \\
\text { and financial system, which would contribute to } \\
\text { the consolidation of the basic ingredients for the } \\
\text { durability of the financial centers of these units and } \\
\text { to improve the efficiency of their performance and } \\
\text { achieve financial stability }\end{array}$ & $\mathrm{O}$ & 1 & 5 & 5 \\
\hline 38 & $\mathrm{O} 2$ & $\begin{array}{l}\text { Establish authority of manpower project } \\
\text { management office }\end{array}$ & $\mathrm{O}$ & 1 & 3 & 3 \\
\hline 39 & $\mathrm{O} 3$ & Develop capabilities & $\mathrm{O}$ & 1 & 6 & 6 \\
\hline 40 & $\mathrm{O} 4$ & Zour refinery project & $\mathrm{O}$ & 1 & 9 & 9 \\
\hline 41 & O5 & $\begin{array}{l}\text { Industrial Strategy for the State of Kuwait in } 2035 \\
\text { draft }\end{array}$ & $\mathrm{O}$ & 1 & 7 & 7 \\
\hline 42 & O6 & $\begin{array}{l}\text { Design and construction of the city's technical } \\
\text { research and services, petroleum and petrochemical } \\
\text { technology }\end{array}$ & $\mathrm{O}$ & 1 & 13 & 13 \\
\hline 43 & $\mathrm{O} 7$ & $\begin{array}{l}\text { The establishment of the Petroleum Research } \\
\text { Center continued KPC }\end{array}$ & $\mathrm{O}$ & 1 & 11 & 11 \\
\hline 44 & $\mathrm{O} 8$ & Automating licenses commercial services & $\mathrm{O}$ & 1 & 1 & 1 \\
\hline 45 & O9 & $\begin{array}{l}\text { Reconstruction of the } 5 \text { centers of commercial } \\
\text { licenses (Mansuriya - Around Me - Khaitan - Back } \\
\text { - Jahra) }\end{array}$ & $\mathrm{O}$ & 1 & 6 & 6 \\
\hline 46 & $\mathrm{O} 10$ & $\begin{array}{l}\text { Support cooperation between the research and } \\
\text { development, production, and service sectors of the } \\
\text { private sector and state institutions }\end{array}$ & $\mathrm{O}$ & 1 & 4 & 4 \\
\hline 47 & O11 & $\begin{array}{l}\text { The contribution of scientific research and } \\
\text { development institutions in support of plans and } \\
\text { programs of technological development in Kuwaiti } \\
\text { private sector }\end{array}$ & $\mathrm{O}$ & 1 & 2 & 2 \\
\hline 48 & $\mathrm{O} 12$ & Technological Center for Intellectual Property & $\mathrm{O}$ & 1 & 10 & 10 \\
\hline 49 & $\mathrm{O} 13$ & $\begin{array}{l}\text { Empowerment of women in community } \\
\text { development }\end{array}$ & $\mathrm{O}$ & 1 & 5 & 5 \\
\hline 50 & O14 & Training center, studies, and Research on Women & $\mathrm{O}$ & 1 & 8 & 8 \\
\hline 51 & $\mathrm{O} 15$ & $\begin{array}{l}\text { Craft skills and economic development for Kuwaiti } \\
\text { women }\end{array}$ & $\mathrm{O}$ & 1 & 4 & 4 \\
\hline
\end{tabular}


Table 3. Continued

\begin{tabular}{|c|c|c|c|c|c|c|}
\hline \multirow[t]{2}{*}{ Project } & \multirow[t]{2}{*}{$\begin{array}{l}\text { Project } \\
\text { Code }\end{array}$} & \multirow[t]{2}{*}{ Name } & $\begin{array}{l}\text { Project } \\
\text { Type }\end{array}$ & \multirow[t]{2}{*}{$\begin{array}{c}\text { Project } \\
\text { Selection }\end{array}$} & \multirow[t]{2}{*}{$\begin{array}{l}\text { Total Project } \\
\text { Contributions }\end{array}$} & \multirow[t]{2}{*}{$\begin{array}{c}\text { Portfolio } \\
\text { Contributions }\end{array}$} \\
\hline & & & $(\mathbf{E}, \mathbf{T}, \mathbf{O})$ & & & \\
\hline 52 & O16 & $\begin{array}{l}\text { Building new reservoirs North LNG Mina Al- } \\
\text { Ahmadi refinery }\end{array}$ & $\mathrm{O}$ & 1 & 4 & 4 \\
\hline 53 & O17 & $\begin{array}{l}\text { Project olefins and aromatics second third is } \\
\text { integrated with Al-Zour refinery }\end{array}$ & $\mathrm{O}$ & 1 & 8 & 8 \\
\hline 54 & O18 & $\begin{array}{l}\text { Enhance the export capacity of industrial plants } \\
\text { exportable cooperation with international } \\
\text { organizations }\end{array}$ & $\mathrm{O}$ & 1 & 5 & 5 \\
\hline 55 & O19 & $\begin{array}{l}\text { The creation, delivery, and operation and } \\
\text { maintenance of the infrastructure of the industrial } \\
\text { zone Shedadiya }\end{array}$ & $\mathrm{O}$ & 1 & 2 & 2 \\
\hline 56 & $\mathrm{O} 20$ & $\begin{array}{l}\text { And implementation of the national plan for } \\
\text { business continuity and disaster management mode }\end{array}$ & $\mathrm{O}$ & 1 & 6 & 6 \\
\hline 57 & $\mathrm{O} 21$ & $\begin{array}{l}\text { Automation of procedures in the management of } \\
\text { public services }\end{array}$ & $\mathrm{O}$ & 1 & 9 & 9 \\
\hline 58 & $\mathrm{O} 22$ & $\begin{array}{l}\text { Project update databases and information systems } \\
\text { and the development of statistical information } \\
\text { system of civil services }\end{array}$ & $\mathrm{O}$ & 1 & 6 & 6 \\
\hline 59 & $\mathrm{O} 23$ & $\begin{array}{l}\text { The geographical spread of the card delivery } \\
\text { devices and devices version and prompt delivery of } \\
\text { the card through a subsidiary body of the centers } \\
\text { in all provinces }\end{array}$ & $\mathrm{O}$ & 1 & 4 & 4 \\
\hline 60 & $\mathrm{O} 24$ & $\begin{array}{l}\text { To facilitate customs procedures Aljmarkih- mall } \\
\text { study }\end{array}$ & $\mathrm{O}$ & 1 & 7 & 7 \\
\hline 61 & $\mathrm{O} 25$ & $\begin{array}{l}\text { Deepening the waterway between the Earth and the } \\
\text { head of the island of Failaka and deepen the port of } \\
\text { transportation on the island }\end{array}$ & $\mathrm{O}$ & 1 & 4 & 4 \\
\hline 62 & $\mathrm{O} 26$ & $\begin{array}{l}\text { Build liquefied gas tankers to load } 58 \text { tons meters } \\
\text { per inhabitant carrier (VLGC) }\end{array}$ & $\mathrm{O}$ & 1 & 10 & 10 \\
\hline 63 & $\mathrm{O} 27$ & Reload systems and infrastructure for ports, Kuwait & $\mathrm{O}$ & 1 & 12 & 12 \\
\hline 64 & $\mathrm{O} 28$ & $\begin{array}{l}\text { The development of the eastern runway airport and } \\
\text { the establishment of the third runway }\end{array}$ & $\mathrm{O}$ & 1 & 5 & 5 \\
\hline 65 & O29 & $\begin{array}{l}\text { The development of the eastern runway at the } \\
\text { international airport }\end{array}$ & $\mathrm{O}$ & 1 & 8 & 8 \\
\hline 66 & $\mathrm{O} 30$ & The new air traffic control tower & $\mathrm{O}$ & 1 & 7 & 7 \\
\hline 67 & $\mathrm{O} 31$ & Kuwait Airport expansion project Terminal (2) & $\mathrm{O}$ & 1 & 5 & 5 \\
\hline 68 & $\mathrm{O} 32$ & $\begin{array}{l}\text { Determine the overall strategies of the Kuwaiti } \\
\text { ports and ports of Business Development }\end{array}$ & $\mathrm{O}$ & 1 & 8 & 8 \\
\hline 69 & $\mathrm{O} 33$ & $\begin{array}{l}\text { Increase the depth and width of the navigation } \\
\text { channel of the port of Shuwaikh }\end{array}$ & $\mathrm{O}$ & 1 & 6 & 6 \\
\hline 70 & $\mathrm{O} 34$ & $\begin{array}{l}\text { Supply, installation, and maintenance of electricity } \\
\text { and water meter system with electronic automatic } \\
\text { meter reading and data collection system }\end{array}$ & $\mathrm{O}$ & 1 & 9 & 9 \\
\hline 71 & $\mathrm{O} 35$ & $\begin{array}{l}\text { Supply, installation, and operation of photovoltaic } \\
\text { panels on the roofs of government buildings }\end{array}$ & $\mathrm{O}$ & 1 & 7 & 7 \\
\hline 72 & $\mathrm{O} 36$ & Al-Khairan city project & $\mathrm{O}$ & 1 & 5 & 5 \\
\hline 73 & $\mathrm{O} 37$ & Al-Matla city project - design & $\mathrm{O}$ & 1 & 3 & 3 \\
\hline 74 & $\mathrm{O} 38$ & Low-cost-housing company & $\mathrm{O}$ & 1 & 7 & 7 \\
\hline
\end{tabular}


Table 3. Continued

\begin{tabular}{|c|c|c|c|c|c|c|}
\hline \multirow[t]{2}{*}{ Project } & \multirow[t]{2}{*}{$\begin{array}{l}\text { Project } \\
\text { Code }\end{array}$} & \multirow[t]{2}{*}{ Name } & $\begin{array}{l}\text { Project } \\
\text { Type }\end{array}$ & \multirow[t]{2}{*}{$\begin{array}{l}\text { Project } \\
\text { Selection }\end{array}$} & \multirow[t]{2}{*}{$\begin{array}{l}\text { Total Project } \\
\text { Contributions }\end{array}$} & \multirow[t]{2}{*}{$\begin{array}{c}\text { Portfolio } \\
\text { Contributions }\end{array}$} \\
\hline & & & $(\mathbf{E}, \mathbf{T}, \mathbf{O})$ & & & \\
\hline 75 & O39 & Provide housing units (4 projects) & $\mathrm{O}$ & 1 & 6 & 6 \\
\hline 76 & $\mathrm{O} 40$ & Environmental control system & $\mathrm{O}$ & 1 & 8 & 8 \\
\hline 77 & $\mathrm{O} 41$ & $\begin{array}{l}\text { Design and construction of the power plant from } \\
\text { renewable sources facilities (with a capacity of } \\
75-100 \mathrm{MW} \text { ) }\end{array}$ & $\mathrm{O}$ & 1 & 9 & 9 \\
\hline 78 & $\mathrm{O} 42$ & $\begin{array}{l}\text { Electric power generation from renewable sources } \\
\text { station (with a capacity of } 75-100 \mathrm{MW} \text { ) }\end{array}$ & $\mathrm{O}$ & 1 & 8 & 8 \\
\hline 79 & $\mathrm{O} 43$ & $\begin{array}{l}\text { Study and evaluation of the implementation of pilot } \\
\text { specialized research station to develop advanced } \\
\text { technology for water desalination and renewable } \\
\text { energy }\end{array}$ & $\mathrm{O}$ & 1 & 3 & 3 \\
\hline 80 & $\mathrm{O} 44$ & $\begin{array}{l}\text { Study and evaluation of the typical specialized } \\
\text { research station to develop advanced technology } \\
\text { for water desalination and renewable energy }\end{array}$ & $\mathrm{O}$ & 1 & 2 & 2 \\
\hline 81 & $\mathrm{O} 45$ & Environmental fuel project & $\mathrm{O}$ & 1 & 4 & 4 \\
\hline 82 & $\mathrm{O} 46$ & Development of health services for school project & $\mathrm{O}$ & 1 & 6 & 6 \\
\hline 83 & $\mathrm{O} 47$ & $\begin{array}{l}\text { Prevention and response to chronic non- } \\
\text { communicable diseases }\end{array}$ & $\mathrm{O}$ & 1 & 5 & 5 \\
\hline 84 & $\mathrm{O} 48$ & Project activating the role of health information & $\mathrm{O}$ & 1 & 4 & 4 \\
\hline 85 & O49 & $\begin{array}{l}\text { Support the role of the private sector in the field of } \\
\text { health project }\end{array}$ & $\mathrm{O}$ & 1 & 8 & 8 \\
\hline 86 & O50 & The development of occupational health services & $\mathrm{O}$ & 1 & 7 & 7 \\
\hline 87 & O51 & $\begin{array}{l}\text { The development of primary health care services } \\
\text { project }\end{array}$ & $\mathrm{O}$ & 1 & 9 & 9 \\
\hline 88 & O52 & Build public sports centers / facilities (4 projects) & $\mathrm{O}$ & 1 & 5 & 5 \\
\hline 89 & O53 & $\begin{array}{l}\text { Encourage and motivate the practice of sport in } \\
\text { society }\end{array}$ & $\mathrm{O}$ & 1 & 2 & 2 \\
\hline 90 & O54 & Sport support schools, colleges, and universities & $\mathrm{O}$ & 1 & 1 & 1 \\
\hline 91 & O55 & $\begin{array}{l}\text { Ambulance Center's main hospital building in } \\
\text { Jahra }\end{array}$ & $\mathrm{O}$ & 1 & 6 & 6 \\
\hline 92 & O56 & $\begin{array}{l}\text { Children's Hospital building in Mubarak Al- } \\
\text { Kabeer }\end{array}$ & $\mathrm{O}$ & 1 & 3 & 3 \\
\hline 93 & O57 & $\begin{array}{l}\text { Improve quality of health services in Kuwait ( } 2 \\
\text { projects) }\end{array}$ & $\mathrm{O}$ & 1 & 4 & 4 \\
\hline 94 & O58 & New building Adan Hospital & $\mathrm{O}$ & 1 & 8 & 8 \\
\hline 95 & O59 & New building Amiri Hospital & $\mathrm{O}$ & 1 & 7 & 7 \\
\hline 6 & O60 & New building Ibn Sina Hospital & $\mathrm{O}$ & 1 & 5 & 5 \\
\hline 97 & O61 & New building Razi Hospital & $\mathrm{O}$ & 1 & 2 & 2 \\
\hline 98 & O62 & New buildings Farwaniya Hospital & $\mathrm{O}$ & 1 & 4 & 4 \\
\hline 99 & O63 & New Morning Hospital & $\mathrm{O}$ & 1 & 6 & 6 \\
\hline 100 & O64 & Project to ensure the safety of patients & $\mathrm{O}$ & 1 & 9 & 9 \\
\hline 101 & O65 & The development of the blood bank services & $\mathrm{O}$ & 1 & 7 & 7 \\
\hline 102 & O66 & Jaber Al-Ahmad Hospital - South Surra & $\mathrm{O}$ & 1 & 5 & 5 \\
\hline 103 & O67 & Police Hospital & $\mathrm{O}$ & 0 & 4 & 0 \\
\hline
\end{tabular}


Table 3. Continued

\begin{tabular}{|c|c|c|c|c|c|c|}
\hline \multirow[t]{2}{*}{ Project } & \multirow[t]{2}{*}{$\begin{array}{l}\text { Project } \\
\text { Code }\end{array}$} & \multirow[t]{2}{*}{ Name } & $\begin{array}{l}\text { Project } \\
\text { Type }\end{array}$ & \multirow[t]{2}{*}{$\begin{array}{c}\text { Project } \\
\text { Selection }\end{array}$} & \multirow[t]{2}{*}{$\begin{array}{l}\text { Total Project } \\
\text { Contributions }\end{array}$} & \multirow[t]{2}{*}{$\begin{array}{c}\text { Portfolio } \\
\text { Contributions }\end{array}$} \\
\hline & & & $(\mathbf{E}, \mathbf{T}, \mathbf{O})$ & & & \\
\hline 104 & O68 & Build rehabilitation center with home-care services & $\mathrm{O}$ & 0 & 6 & 0 \\
\hline 105 & O69 & $\begin{array}{l}\text { Take advantage of the training and continuing } \\
\text { education capabilities of private universities }\end{array}$ & $\mathrm{O}$ & 1 & 6 & 6 \\
\hline 106 & $\mathrm{O} 70$ & $\begin{array}{l}\text { Develop and implement a training program for } \\
\text { Kuwaiti professionals }\end{array}$ & $\mathrm{O}$ & 0 & 5 & 0 \\
\hline 107 & O71 & Training centers, school districts & $\mathrm{O}$ & 0 & 8 & 0 \\
\hline 108 & $\mathrm{O} 72$ & Identify and syndicate vocational training needs & $\mathrm{O}$ & 1 & 9 & 9 \\
\hline 109 & O73 & Curriculum Development & $\mathrm{O}$ & 1 & 5 & 5 \\
\hline 110 & O74 & $\begin{array}{l}\text { The development of educational and school } \\
\text { departments and achieve professional development } \\
\text { of leaders and workers in general education and all } \\
\text { other types of education }\end{array}$ & $\mathrm{O}$ & 1 & 8 & 8 \\
\hline 111 & O75 & $\begin{array}{l}\text { Support research and development activity in the } \\
\text { private universities }\end{array}$ & $\mathrm{O}$ & 0 & 9 & 0 \\
\hline 112 & O76 & $\begin{array}{l}\text { Expansion and development of the Faculty of } \\
\text { Dentistry Clinics }\end{array}$ & $\mathrm{O}$ & 0 & 5 & 0 \\
\hline 113 & O77 & $\begin{array}{l}\text { Promotion and development of infrastructure for } \\
\text { scientific research at Kuwait University }\end{array}$ & $\mathrm{O}$ & 1 & 4 & 4 \\
\hline 114 & $\mathrm{O} 78$ & $\begin{array}{l}\text { Introduce an electronic learning system across } \\
\text { educational institutions in Kuwait (5 projects) }\end{array}$ & $\mathrm{O}$ & 1 & 21 & 21 \\
\hline 115 & O79 & National tests for university admission & $\mathrm{O}$ & 1 & 7 & 7 \\
\hline 116 & O80 & $\begin{array}{l}\text { Ensure quality control academic and professional } \\
\text { accreditation Authority }\end{array}$ & $\mathrm{O}$ & 0 & 2 & 0 \\
\hline 117 & O81 & Establishment of vocational skills center & $\mathrm{O}$ & 1 & 4 & 4 \\
\hline 118 & O82 & $\begin{array}{l}\text { Kuwait competitive in the international promotion } \\
\text { of indicators }\end{array}$ & $\mathrm{O}$ & 1 & 6 & 6 \\
\hline 119 & O83 & Activating the role of economic diplomacy & $\mathrm{O}$ & 0 & 6 & 0 \\
\hline 120 & O84 & $\begin{array}{l}\text { Strengthening the role and efforts of the State of } \\
\text { Kuwait in the field of human rights }\end{array}$ & $\mathrm{O}$ & 0 & 5 & 0 \\
\hline 121 & O85 & $\begin{array}{l}\text { Enhance the image of Kuwait internationally } \\
\text { through the use of public relations firms }\end{array}$ & $\mathrm{O}$ & 1 & 9 & 9 \\
\hline 122 & O86 & $\begin{array}{l}\text { Exhibitions of Islamic art inside and outside the } \\
\text { State of Kuwait }\end{array}$ & $\mathrm{O}$ & 0 & 8 & 0 \\
\hline 123 & O87 & $\begin{array}{l}\text { Cultural and artistic exchange project inside and } \\
\text { outside Kuwait }\end{array}$ & $\mathrm{O}$ & 1 & 10 & 10 \\
\hline 124 & O88 & $\begin{array}{l}\text { Publish and distribute Kuwaiti creations outside } \\
\text { Kuwait }\end{array}$ & $\mathrm{O}$ & 0 & 2 & 0 \\
\hline & & & Sum $=$ & 108 & 730 & 645 \\
\hline
\end{tabular}


Table 4. Satisfaction of Goals 1 and 2

\begin{tabular}{|c|c|c|c|c|c|c|c|}
\hline & & & & & & \multicolumn{2}{|c|}{ Deviations } \\
\hline & & & & & & Amount & Amount \\
\hline Project \# & Project Type & Project Selection & Level & Relation & Project Goal & Over & Under \\
\hline 3 & $\mathrm{~T} 3$ & 1 & 1 & $=$ & 1 & 0 & 0 \\
\hline 4 & $\mathrm{~T} 4$ & 1 & 1 & $=$ & 1 & 0 & 0 \\
\hline 6 & T6 & 1 & 1 & $=$ & 1 & 0 & 0 \\
\hline 8 & $\mathrm{~T} 8$ & 1 & 1 & $=$ & 1 & 0 & 0 \\
\hline 9 & T9 & 1 & 1 & $=$ & 1 & 0 & 0 \\
\hline 10 & $\mathrm{~T} 10$ & 1 & 1 & $=$ & 1 & 0 & 0 \\
\hline 11 & T11 & 1 & 1 & $=$ & 1 & 0 & 0 \\
\hline 12 & $\mathrm{~T} 12$ & 1 & 1 & $=$ & 1 & 0 & 0 \\
\hline 15 & T15 & 1 & 1 & $=$ & 1 & 0 & 0 \\
\hline 18 & E1 & 1 & 1 & $=$ & 1 & 0 & 0 \\
\hline 19 & E2 & 1 & 1 & $=$ & 1 & 0 & 0 \\
\hline 20 & E3 & 1 & 1 & $=$ & 1 & 0 & 0 \\
\hline 21 & E4 & 1 & 1 & $=$ & 1 & 0 & 0 \\
\hline 22 & E5 & 1 & 1 & $=$ & 1 & 0 & 0 \\
\hline 23 & E6 & 1 & 1 & $=$ & 1 & 0 & 0 \\
\hline 24 & E7 & 1 & 1 & $=$ & 1 & 0 & 0 \\
\hline 25 & E8 & 1 & 1 & $=$ & 1 & 0 & 0 \\
\hline 26 & E9 & 1 & 1 & $=$ & 1 & 0 & 0 \\
\hline 27 & E10 & 1 & 1 & $=$ & 1 & 0 & 0 \\
\hline 28 & E11 & 1 & 1 & $=$ & 1 & 0 & 0 \\
\hline 29 & E12 & 1 & 1 & $=$ & 1 & 0 & 0 \\
\hline 30 & E13 & 1 & 1 & $=$ & 1 & 0 & 0 \\
\hline 31 & E14 & 1 & 1 & $=$ & 1 & 0 & 0 \\
\hline 32 & E15 & 1 & 1 & $=$ & 1 & 0 & 0 \\
\hline 33 & E16 & 1 & 1 & $=$ & 1 & 0 & 0 \\
\hline 34 & E17 & 1 & 1 & $=$ & 1 & 0 & 0 \\
\hline 35 & E18 & 1 & 1 & $=$ & 1 & 0 & 0 \\
\hline 36 & E19 & 1 & 1 & $=$ & 1 & 0 & 0 \\
\hline 37 & $\mathrm{O} 1$ & 1 & 1 & $=$ & 1 & 0 & 0 \\
\hline 38 & $\mathrm{O} 2$ & 1 & 1 & $=$ & 1 & 0 & 0 \\
\hline 39 & $\mathrm{O} 3$ & 1 & 1 & $=$ & 1 & 0 & 0 \\
\hline 40 & $\mathrm{O} 4$ & 1 & 1 & $=$ & 1 & 0 & 0 \\
\hline 41 & O5 & 1 & 1 & $=$ & 1 & 0 & 0 \\
\hline 42 & O6 & 1 & 1 & $=$ & 1 & 0 & 0 \\
\hline 43 & O7 & 1 & 1 & $=$ & 1 & 0 & 0 \\
\hline
\end{tabular}


Table 4. Continued

\begin{tabular}{|c|c|c|c|c|c|c|c|}
\hline & & & & & & \multicolumn{2}{|c|}{ Deviations } \\
\hline & & & & & & Amount & Amount \\
\hline Project \# & Project Type & Project Selection & Level & Relation & Project Goal & Over & Under \\
\hline 44 & O8 & 1 & 1 & $=$ & 1 & 0 & 0 \\
\hline 45 & O9 & 1 & 1 & $=$ & 1 & 0 & 0 \\
\hline 46 & O10 & 1 & 1 & $=$ & 1 & 0 & 0 \\
\hline 47 & O11 & 1 & 1 & $=$ & 1 & 0 & 0 \\
\hline 48 & $\mathrm{O} 12$ & 1 & 1 & $=$ & 1 & 0 & 0 \\
\hline 49 & $\mathrm{O} 13$ & 1 & 1 & $=$ & 1 & 0 & 0 \\
\hline 50 & $\mathrm{O} 14$ & 1 & 1 & $=$ & 1 & 0 & 0 \\
\hline 51 & O15 & 1 & 1 & $=$ & 1 & 0 & 0 \\
\hline 52 & O16 & 1 & 1 & $=$ & 1 & 0 & 0 \\
\hline 53 & O17 & 1 & 1 & $=$ & 1 & 0 & 0 \\
\hline 54 & $\mathrm{O} 18$ & 1 & 1 & $=$ & 1 & 0 & 0 \\
\hline 55 & O19 & 1 & 1 & $=$ & 1 & 0 & 0 \\
\hline 56 & $\mathrm{O} 20$ & 1 & 1 & $=$ & 1 & 0 & 0 \\
\hline 57 & $\mathrm{O} 21$ & 1 & 1 & $=$ & 1 & 0 & 0 \\
\hline 58 & $\mathrm{O} 22$ & 1 & 1 & $=$ & 1 & 0 & 0 \\
\hline 59 & $\mathrm{O} 23$ & 1 & 1 & $=$ & 1 & 0 & 0 \\
\hline 60 & $\mathrm{O} 24$ & 1 & 1 & $=$ & 1 & 0 & 0 \\
\hline 61 & $\mathrm{O} 25$ & 1 & 1 & $=$ & 1 & 0 & 0 \\
\hline 62 & O26 & 1 & 1 & $=$ & 1 & 0 & 0 \\
\hline 63 & $\mathrm{O} 27$ & 1 & 1 & $=$ & 1 & 0 & 0 \\
\hline 64 & $\mathrm{O} 28$ & 1 & 1 & $=$ & 1 & 0 & 0 \\
\hline 65 & O29 & 1 & 1 & $=$ & 1 & 0 & 0 \\
\hline 66 & O30 & 1 & 1 & $=$ & 1 & 0 & 0 \\
\hline 67 & O31 & 1 & 1 & $=$ & 1 & 0 & 0 \\
\hline 68 & $\mathrm{O} 32$ & 1 & 1 & $=$ & 1 & 0 & 0 \\
\hline 69 & O33 & 1 & 1 & $=$ & 1 & 0 & 0 \\
\hline 70 & O34 & 1 & 1 & $=$ & 1 & 0 & 0 \\
\hline 71 & O35 & 1 & 1 & $=$ & 1 & 0 & 0 \\
\hline 72 & O36 & 1 & 1 & $=$ & 1 & 0 & 0 \\
\hline 73 & O37 & 1 & 1 & $=$ & 1 & 0 & 0 \\
\hline 74 & O38 & 1 & 1 & $=$ & 1 & 0 & 0 \\
\hline 75 & O39 & 1 & 1 & $=$ & 1 & 0 & 0 \\
\hline 76 & O40 & 1 & 1 & $=$ & 1 & 0 & 0 \\
\hline 77 & O41 & 1 & 1 & $=$ & 1 & 0 & 0 \\
\hline 78 & O42 & 1 & 1 & $=$ & 1 & 0 & 0 \\
\hline
\end{tabular}


Table 4. Continued

\begin{tabular}{|c|c|c|c|c|c|c|c|}
\hline & & & & & & \multicolumn{2}{|c|}{ Deviations } \\
\hline & & & & & & Amount & Amount \\
\hline Project \# & Project Type & Project Selection & Level & Relation & Project Goal & Over & Under \\
\hline 79 & O43 & 1 & 1 & $=$ & 1 & 0 & 0 \\
\hline 80 & O44 & 1 & 1 & $=$ & 1 & 0 & 0 \\
\hline 81 & $\mathrm{O} 45$ & 1 & 1 & $=$ & 1 & 0 & 0 \\
\hline 82 & O46 & 1 & 1 & $=$ & 1 & 0 & 0 \\
\hline 83 & O47 & 1 & 1 & $=$ & 1 & 0 & 0 \\
\hline 84 & O48 & 1 & 1 & $=$ & 1 & 0 & 0 \\
\hline 85 & O49 & 1 & 1 & $=$ & 1 & 0 & 0 \\
\hline 86 & O50 & 1 & 1 & $=$ & 1 & 0 & 0 \\
\hline 87 & O51 & 1 & 1 & $=$ & 1 & 0 & 0 \\
\hline 88 & O52 & 1 & 1 & $=$ & 1 & 0 & 0 \\
\hline 89 & O53 & 1 & 1 & $=$ & 1 & 0 & 0 \\
\hline 90 & O54 & 1 & 1 & $=$ & 1 & 0 & 0 \\
\hline 91 & O55 & 1 & 1 & $=$ & 1 & 0 & 0 \\
\hline 92 & O56 & 1 & 1 & $=$ & 1 & 0 & 0 \\
\hline 93 & O57 & 1 & 1 & $=$ & 1 & 0 & 0 \\
\hline 94 & O58 & 1 & 1 & $=$ & 1 & 0 & 0 \\
\hline 95 & O59 & 1 & 1 & $=$ & 1 & 0 & 0 \\
\hline 96 & O60 & 1 & 1 & $=$ & 1 & 0 & 0 \\
\hline 97 & O61 & 1 & 1 & $=$ & 1 & 0 & 0 \\
\hline 98 & O62 & 1 & 1 & $=$ & 1 & 0 & 0 \\
\hline 99 & O63 & 1 & 1 & $=$ & 1 & 0 & 0 \\
\hline 100 & O64 & 1 & 1 & $=$ & 1 & 0 & 0 \\
\hline 101 & O65 & 1 & 1 & $=$ & 1 & 0 & 0 \\
\hline 102 & O66 & 1 & 1 & $=$ & 1 & 0 & 0 \\
\hline
\end{tabular}


Table 5. Satisfaction of Goals 3-8




Table 6. Satisfaction of Goal 9 for years $1-5$ and Goal 10

\begin{tabular}{|c|c|c|c|c|c|}
\hline & & & & \multicolumn{2}{|c|}{ Deviations } \\
\hline \multirow[t]{4}{*}{ Goal 9-Year1 } & & & & Amount & Amount \\
\hline & Level & Relation & Project Goal & Over & Under \\
\hline & 0 & $<=$ & 0 & 0 & 0 \\
\hline & & & & \multicolumn{2}{|c|}{ Deviations } \\
\hline \multirow[t]{4}{*}{ Goal 9-Year2 } & & & & Amount & Amount \\
\hline & Level & Relation & Project Goal & Over & Under \\
\hline & -330000 & $<=$ & 0 & 0 & 330000 \\
\hline & & & & \multicolumn{2}{|c|}{ Deviations } \\
\hline \multirow[t]{4}{*}{ Goal 9-Year3 } & & & & Amount & Amount \\
\hline & Level & Relation & Project Goal & Over & Under \\
\hline & -50000 & $<=$ & 0 & 0 & 50000 \\
\hline & & & & \multicolumn{2}{|c|}{ Deviations } \\
\hline \multirow[t]{4}{*}{ Goal 9-Year4 } & & & & Amount & Amount \\
\hline & Level & Relation & Project Goal & Over & Under \\
\hline & -10000 & $<=$ & 0 & 0 & 10000 \\
\hline & & & & \multicolumn{2}{|c|}{ Deviations } \\
\hline \multirow[t]{4}{*}{ Goal 9-Year5 } & & & & Amount & Amount \\
\hline & Level & Relation & Project Goal & Over & Under \\
\hline & -1440000 & $<=$ & 0 & 0 & 1440000 \\
\hline & & 51.39 & & \multicolumn{2}{|c|}{ Deviations } \\
\hline \multirow[t]{3}{*}{ Goal 10} & & & & Amount & Amount \\
\hline & Level & relation & Project Goal & Over & Under \\
\hline & 32.10 & $<=$ & 30 & 2.1 & 0 \\
\hline
\end{tabular}


International Journal of Operations Research and Information Systems

Volume 12 - Issue 4

Table 7. The objective function for priorities $P_{1}-P_{9}$

\begin{tabular}{|l|r|}
\hline P1 & 0 \\
\hline P2 & 0 \\
\hline P3 & 0 \\
\hline P4 & 0 \\
\hline P5 & 0 \\
\hline P6 & 0 \\
\hline P7 & 0 \\
\hline P8 & 0 \\
\hline P9 & 0 \\
\hline
\end{tabular}


Table 8. Project portfolio for each global index

\begin{tabular}{|c|c|c|c|c|}
\hline Global Index & Project Code & $\begin{array}{c}\text { Project Selection } \\
\text { Status }\end{array}$ & $\begin{array}{c}\text { Project } \\
\text { Contribution* }\end{array}$ & Improvement \\
\hline \multicolumn{5}{|l|}{1} \\
\hline & T1 & $\mathbf{0}$ & 1 & $\mathbf{0}$ \\
\hline & E1 & 1 & 4 & 4 \\
\hline & E2 & 1 & 6 & 6 \\
\hline & 01 & 1 & 5 & 5 \\
\hline & Total & 3 & 16 & 15 \\
\hline \multicolumn{5}{|l|}{2} \\
\hline & E3 & 1 & 9 & 9 \\
\hline & $\mathbf{O 2}$ & 1 & 3 & 3 \\
\hline & $\mathbf{O 3}$ & 1 & 6 & 6 \\
\hline & Total & 3 & 18 & 18 \\
\hline \multicolumn{5}{|l|}{3} \\
\hline & E4 & 1 & 8 & 8 \\
\hline & E5 & 1 & 5 & 5 \\
\hline & E6 & 1 & 3 & 3 \\
\hline & Total & 3 & 16 & 16 \\
\hline \multicolumn{5}{|l|}{4} \\
\hline & Total & $\mathbf{0}$ & $\mathbf{0}$ & $\mathbf{0}$ \\
\hline \multicolumn{5}{|l|}{5} \\
\hline & $\mathbf{T 2}$ & 0 & 5 & 0 \\
\hline & T3 & 1 & 5 & 5 \\
\hline & T4 & 1 & 2 & 2 \\
\hline & T5 & $\mathbf{0}$ & 6 & $\mathbf{0}$ \\
\hline & Total & 2 & 18 & 7 \\
\hline \multicolumn{5}{|l|}{6} \\
\hline & E7 & 1 & 3 & 3 \\
\hline & 013 & 1 & 5 & 5 \\
\hline & 014 & 1 & 8 & 8 \\
\hline & 015 & 1 & 4 & 4 \\
\hline & Total & 4 & 20 & 20 \\
\hline \multicolumn{5}{|l|}{7} \\
\hline & T6 & 1 & 3 & 3 \\
\hline & 016 & 1 & 4 & 4 \\
\hline & 017 & 1 & 8 & 8 \\
\hline & 018 & 1 & 5 & 5 \\
\hline & 019 & 1 & 2 & 2 \\
\hline & Total & 5 & 22 & 22 \\
\hline
\end{tabular}


International Journal of Operations Research and Information Systems

Volume $12 \cdot$ Issue 4

Table 8. Continued

\begin{tabular}{|c|c|c|c|c|}
\hline Global Index & Project Code & $\begin{array}{l}\text { Project Selection } \\
\text { Status }\end{array}$ & $\begin{array}{c}\text { Project } \\
\text { Contribution* }\end{array}$ & Improvement \\
\hline \multicolumn{5}{|l|}{8} \\
\hline & T7 & 1 & 10 & 10 \\
\hline & T8 & 1 & 4 & 4 \\
\hline & E8 & 1 & 7 & 7 \\
\hline & $\mathbf{O 2 0}$ & 1 & 6 & 6 \\
\hline & 021 & 1 & 9 & 9 \\
\hline & $\mathbf{O 2 2}$ & 1 & 6 & 6 \\
\hline & $\mathbf{O 2 3}$ & 1 & 4 & 4 \\
\hline & Total & 7 & 46 & 46 \\
\hline \multicolumn{5}{|l|}{9} \\
\hline & E9 & 1 & 5 & 5 \\
\hline & 024 & 1 & 7 & 7 \\
\hline & $\mathbf{O 2 5}$ & 1 & 4 & 4 \\
\hline & Total & 3 & 16 & 16 \\
\hline \multicolumn{5}{|l|}{10} \\
\hline & T9 & 1 & 2 & 2 \\
\hline & T10 & 1 & 8 & 8 \\
\hline & E10 & 1 & 4 & 4 \\
\hline & 026 & 1 & 10 & 10 \\
\hline & $\mathbf{O} 27$ & 1 & 12 & 12 \\
\hline & $\mathbf{O 2 8}$ & 1 & 5 & 5 \\
\hline & $\mathbf{O 2 9}$ & 1 & 8 & 8 \\
\hline & $\mathbf{O 3 0}$ & 1 & 7 & 7 \\
\hline & Total & 8 & 56 & 56 \\
\hline \multicolumn{5}{|l|}{11} \\
\hline & 031 & 1 & 5 & 5 \\
\hline & $\mathbf{O 3 2}$ & 1 & 8 & 8 \\
\hline & $\mathbf{O 3 3}$ & 1 & 6 & 6 \\
\hline & Total & 3 & 19 & 19 \\
\hline \multicolumn{5}{|l|}{12} \\
\hline & 034 & 1 & 9 & 9 \\
\hline & $\mathbf{O 3 5}$ & 1 & 7 & 7 \\
\hline & Total & 2 & 16 & 16 \\
\hline \multicolumn{5}{|l|}{13} \\
\hline & E11 & 1 & 6 & 6 \\
\hline
\end{tabular}


Table 8. Continued

\begin{tabular}{|c|c|c|c|c|}
\hline Global Index & Project Code & $\begin{array}{c}\text { Project Selection } \\
\text { Status }\end{array}$ & $\begin{array}{c}\text { Project } \\
\text { Contribution* }\end{array}$ & Improvement \\
\hline & 036 & 1 & 5 & 5 \\
\hline & $\mathbf{O 3 7}$ & 1 & 3 & 3 \\
\hline & $\mathbf{O 3 8}$ & 1 & 7 & 7 \\
\hline & O39 & 1 & 6 & 6 \\
\hline & Total & 5 & 27 & 27 \\
\hline \multicolumn{5}{|l|}{14} \\
\hline & T11 & 1 & 6 & 6 \\
\hline & O40 & 1 & 8 & 8 \\
\hline & 041 & 1 & 9 & 9 \\
\hline & 042 & 1 & 8 & 8 \\
\hline & O43 & 1 & 3 & 3 \\
\hline & O44 & 1 & 2 & 2 \\
\hline & 045 & 1 & 4 & 4 \\
\hline & Total & 7 & 40 & 40 \\
\hline \multicolumn{5}{|l|}{15} \\
\hline & T12 & 1 & 8 & 8 \\
\hline & E12 & 1 & 6 & 6 \\
\hline & E13 & 1 & 4 & 4 \\
\hline & 046 & 1 & 6 & 6 \\
\hline & O47 & 1 & 5 & 5 \\
\hline & 048 & 1 & 4 & 4 \\
\hline & O49 & 1 & 8 & 8 \\
\hline & 050 & 1 & 7 & 7 \\
\hline & 051 & 1 & 9 & 9 \\
\hline & 052 & 1 & 5 & 5 \\
\hline & $\mathbf{0 5 3}$ & 1 & 2 & 2 \\
\hline & 054 & 1 & 1 & 1 \\
\hline & 055 & 1 & 6 & 6 \\
\hline & 056 & 1 & 3 & 3 \\
\hline & 057 & 1 & 4 & 4 \\
\hline & 058 & 1 & 8 & 8 \\
\hline & 059 & 1 & 7 & 7 \\
\hline & 060 & 1 & 5 & 5 \\
\hline & 061 & 1 & 2 & 2 \\
\hline & 062 & 1 & 4 & 4 \\
\hline & O63 & 1 & 6 & 6 \\
\hline
\end{tabular}


International Journal of Operations Research and Information Systems

Volume $12 \cdot$ Issue 4

Table 8. Continued

\begin{tabular}{|c|c|c|c|c|}
\hline Global Index & Project Code & $\begin{array}{c}\text { Project Selection } \\
\text { Status }\end{array}$ & $\begin{array}{c}\text { Project } \\
\text { Contribution* }\end{array}$ & Improvement \\
\hline & 064 & 1 & 9 & 9 \\
\hline & 065 & 1 & 7 & 7 \\
\hline & 066 & 1 & 5 & 5 \\
\hline & O67 & 0 & 4 & $\mathbf{0}$ \\
\hline & 068 & $\mathbf{0}$ & 6 & $\mathbf{0}$ \\
\hline & Total & 24 & 141 & 131 \\
\hline \multicolumn{5}{|l|}{16} \\
\hline & T13 & 1 & 15 & 15 \\
\hline & T14 & 0 & 5 & 0 \\
\hline & E14 & 1 & 1 & 1 \\
\hline & E15 & 1 & 1 & 1 \\
\hline & 069 & 1 & 6 & 6 \\
\hline & O70 & 0 & 6 & 0 \\
\hline & 071 & $\mathbf{0}$ & 8 & $\mathbf{0}$ \\
\hline & 072 & 1 & 9 & 9 \\
\hline & Total & 5 & 51 & 32 \\
\hline \multicolumn{5}{|l|}{17} \\
\hline & T15 & 1 & 2 & 2 \\
\hline & T16 & 0 & 0.08 & 0 \\
\hline & T17 & 1 & 7 & 7 \\
\hline & E16 & 1 & 5 & 5 \\
\hline & 073 & 1 & 5 & 5 \\
\hline & 074 & 1 & 8 & 8 \\
\hline & 075 & $\mathbf{0}$ & 9 & $\mathbf{0}$ \\
\hline & 076 & $\mathbf{0}$ & 5 & $\mathbf{0}$ \\
\hline & $\mathbf{O 7 7}$ & 1 & 4 & 4 \\
\hline & $\mathbf{0 7 8}$ & 1 & 21 & 21 \\
\hline & 079 & 1 & 7 & 7 \\
\hline & O80 & 0 & 2 & 0 \\
\hline & 081 & 1 & 4 & 4 \\
\hline & Total & 9 & 79.08 & 63 \\
\hline \multicolumn{5}{|l|}{18} \\
\hline & Total & 0 & 0 & 0 \\
\hline \multicolumn{5}{|l|}{19} \\
\hline & 082 & 1 & 6 & 6 \\
\hline & Total & 1 & 6 & 6 \\
\hline \multicolumn{5}{|l|}{20} \\
\hline & E17 & 1 & 6 & 6 \\
\hline
\end{tabular}


Table 8. Continued

\begin{tabular}{|c|c|c|c|c|}
\hline Global Index & Project Code & $\begin{array}{c}\text { Project Selection } \\
\text { Status }\end{array}$ & $\begin{array}{c}\text { Project } \\
\text { Contribution* }\end{array}$ & Improvement \\
\hline & E18 & 1 & 1 & 1 \\
\hline & E19 & 1 & 1 & 1 \\
\hline & 083 & 0 & 5 & 0 \\
\hline & 084 & 0 & 9 & 9 \\
\hline & 085 & 1 & 8 & 0 \\
\hline & 087 & 1 & 10 & 0 \\
\hline
\end{tabular}

*Project Contribution is fictitious data

Table 9. The projects that are assigned to each index and their contribution to index improvement

\begin{tabular}{|c|c|c|c|c|c|c|c|c|}
\hline $\begin{array}{l}\text { Global } \\
\text { Index }\end{array}$ & Percentile & $\begin{array}{c}\text { No of } \\
\text { Projects }\end{array}$ & $\begin{array}{l}\text { No of } \\
\text { Projects } \\
\text { Selected }\end{array}$ & $\begin{array}{l}\text { Contribution } \\
\text { to Index } \\
\text { improvement }\end{array}$ & $\begin{array}{l}\text { Percentage of } \\
\text { Improvement }\end{array}$ & $\begin{array}{c}\text { New } \\
\text { Percentile }\end{array}$ & $\begin{array}{l}\text { Improvement } \\
\text { Required Per } \\
\text { Plan }\end{array}$ & $\begin{array}{l}\text { Over /Under } \\
\text { Achievement }\end{array}$ \\
\hline 1 & 40 & 4 & 3 & 15 & $38 \%$ & 25 & 5 & 10 \\
\hline 2 & 61 & 3 & 3 & 18 & $30 \%$ & 43 & 10.25 & 7.75 \\
\hline 3 & 51 & 3 & 3 & 16 & $31 \%$ & 35 & 7.75 & 8.25 \\
\hline 4 & 55 & 0 & 0 & 0 & $0 \%$ & 55 & 8.75 & -8.75 \\
\hline 5 & 53 & 4 & 2 & 7 & $13 \%$ & 46 & 8.25 & -1.25 \\
\hline 6 & 40 & 4 & 4 & 20 & $50 \%$ & 20 & 5 & 15 \\
\hline 7 & 49 & 5 & 5 & 22 & $45 \%$ & 27 & 7.25 & 14.75 \\
\hline 8 & 67 & 7 & 7 & 46 & $69 \%$ & 21 & 11.75 & 34.25 \\
\hline 9 & 38 & 3 & 3 & 16 & $42 \%$ & 22 & 4.5 & 11.5 \\
\hline 10 & 53 & 8 & 8 & 56 & $106 \%$ & -3 & 8.25 & 47.75 \\
\hline 11 & 49 & 3 & 3 & 19 & $39 \%$ & 30 & 7.25 & 11.75 \\
\hline 12 & 78 & 2 & 2 & 16 & $21 \%$ & 62 & 14.5 & 1.5 \\
\hline 13 & 20 & 5 & 5 & 27 & $135 \%$ & -7 & 0 & 27 \\
\hline 14 & 43 & 7 & 7 & 40 & $93 \%$ & 3 & 5.75 & 34.25 \\
\hline 15 & 54 & 26 & 24 & 131 & $243 \%$ & -77 & 8.5 & 122.5 \\
\hline 16 & 65 & 8 & 5 & 32 & $49 \%$ & 33 & 11.25 & 20.75 \\
\hline 17 & 69 & 13 & 9 & 63 & $91 \%$ & 6 & 12.25 & 50.75 \\
\hline 18 & 17 & 0 & 0 & 0 & $0 \%$ & 17 & -0.75 & 0.75 \\
\hline 19 & 36 & 1 & 1 & 6 & $17 \%$ & 30 & 4 & 2 \\
\hline 20 & 59 & 9 & 5 & 27 & $46 \%$ & 32 & 9.75 & 17.25 \\
\hline Average $=$ & 51.39 & & Average $=$ & 32.1 & & & & \\
\hline
\end{tabular}


Table 10: fictitious cost and budget available data for goals $4,6,7$, and 9

\begin{tabular}{|c|c|c|c|c|c|c|c|c|c|c|}
\hline Project & $\begin{array}{l}\text { Cost } \\
\text { for year } \\
2015- \\
2016\end{array}$ & $\begin{array}{l}\text { Cost } \\
\text { for year } \\
2016- \\
2017\end{array}$ & $\begin{array}{l}\text { Cost } \\
\text { for year } \\
2017 \text { - } \\
2018\end{array}$ & $\begin{array}{l}\text { Cost } \\
\text { for year } \\
2018- \\
2019\end{array}$ & $\begin{array}{l}\text { Cost } \\
\text { for year } \\
2019 \text { - } \\
2020\end{array}$ & $\begin{array}{l}\text { budget } \\
\text { available } \\
\text { for year } \\
2015- \\
2016\end{array}$ & $\begin{array}{l}\text { budget } \\
\text { available } \\
\text { for year } \\
2016- \\
2017\end{array}$ & $\begin{array}{l}\text { budget } \\
\text { available } \\
\text { for year } \\
2017- \\
2018\end{array}$ & $\begin{array}{l}\text { budget } \\
\text { available } \\
\text { for year } \\
2018- \\
2019\end{array}$ & $\begin{array}{l}\text { budget } \\
\text { available } \\
\text { for year } \\
2019 \text { - } \\
2020\end{array}$ \\
\hline T1 & 250000 & 250000 & 250000 & 250000 & 250000 & 260000 & 240000 & 230000 & 300000 & 300000 \\
\hline $\mathbf{T} 2$ & 1000000 & 1000000 & 1000000 & 1000000 & 1000000 & 900000 & 1200000 & 800000 & 1000000 & 1000000 \\
\hline T5 & 1250000 & 1250000 & 1250000 & 1250000 & 1000000 & 1270000 & 1280000 & 1290000 & 1200000 & 1200000 \\
\hline $\mathbf{T} 7$ & 500000 & 500000 & 500000 & 500000 & 500000 & 450000 & 550000 & 490000 & 500000 & 500000 \\
\hline T13 & 1500000 & 1500000 & 1500000 & 1500000 & 1500000 & 1520000 & 1530000 & 1490000 & 1500000 & 1500000 \\
\hline T14 & 2250000 & 2250000 & 2250000 & 2250000 & 2250000 & 2260000 & 2280000 & 2230000 & 2250000 & 2250000 \\
\hline T16 & 1750000 & 1750000 & 1750000 & 1750000 & 1750000 & 1720000 & 1730000 & 1750000 & 1720000 & 1720000 \\
\hline T17 & 250000 & 250000 & 250000 & 250000 & 250000 & 260000 & 270000 & 250000 & 240000 & 240000 \\
\hline O67 & 250000 & 250000 & 250000 & 250000 & 250000 & 260000 & 240000 & 230000 & 300000 & 300000 \\
\hline 068 & 1000000 & 1000000 & 1000000 & 1000000 & 1000000 & 900000 & 1200000 & 800000 & 1000000 & 1000000 \\
\hline 069 & 1250000 & 1250000 & 1250000 & 1250000 & 1250000 & 1270000 & 1280000 & 1290000 & 1200000 & 1200000 \\
\hline O70 & 500000 & 500000 & 500000 & 500000 & 500000 & 450000 & 550000 & 490000 & 500000 & 500000 \\
\hline O71 & 1500000 & 1500000 & 1500000 & 1500000 & 1500000 & 1520000 & 1530000 & 1490000 & 1500000 & 1500000 \\
\hline O72 & 2250000 & 2250000 & 2250000 & 2250000 & 2000000 & 2260000 & 2280000 & 2230000 & 2250000 & 2250000 \\
\hline 073 & 1750000 & 1750000 & 1750000 & 1750000 & 1750000 & 1720000 & 1730000 & 1750000 & 1720000 & 1720000 \\
\hline 074 & 250000 & 250000 & 250000 & 250000 & 250000 & 260000 & 270000 & 250000 & 240000 & 240000 \\
\hline 075 & 250000 & 250000 & 250000 & 250000 & 250000 & 260000 & 240000 & 230000 & 300000 & 300000 \\
\hline O76 & 1000000 & 1000000 & 1000000 & 1000000 & 1000000 & 900000 & 1200000 & 800000 & 1000000 & 1000000 \\
\hline O77 & 1250000 & 1250000 & 1250000 & 1250000 & 1250000 & 1270000 & 1280000 & 1290000 & 1200000 & 1200000 \\
\hline O78 & 500000 & 500000 & 500000 & 500000 & 500000 & 450000 & 550000 & 490000 & 500000 & 500000 \\
\hline O79 & 1500000 & 1500000 & 1500000 & 1500000 & 1500000 & 1520000 & 1530000 & 1490000 & 1500000 & 1500000 \\
\hline O80 & 2250000 & 2250000 & 2250000 & 2250000 & 2250000 & 2260000 & 2280000 & 2230000 & 2250000 & 2250000 \\
\hline 081 & 1750000 & 1750000 & 1750000 & 1750000 & 1750000 & 1720000 & 1730000 & 1750000 & 1720000 & 1720000 \\
\hline 082 & 250000 & 250000 & 250000 & 250000 & 250000 & 260000 & 270000 & 250000 & 240000 & 240000 \\
\hline 083 & 250000 & 250000 & 250000 & 250000 & 250000 & 260000 & 240000 & 230000 & 300000 & 300000 \\
\hline 084 & 1000000 & 1000000 & 1000000 & 1000000 & 1000000 & 900000 & 1200000 & 800000 & 1000000 & 1000000 \\
\hline 085 & 1250000 & 1250000 & 1250000 & 1250000 & 1250000 & 1270000 & 1280000 & 1290000 & 1200000 & 1200000 \\
\hline O86 & 500000 & 500000 & 500000 & 500000 & 500000 & 450000 & 550000 & 490000 & 500000 & 500000 \\
\hline O87 & 1500000 & 1500000 & 1500000 & 1500000 & 1500000 & 1520000 & 1530000 & 1490000 & 1500000 & 1500000 \\
\hline O88 & 2250000 & 2250000 & 2250000 & 2250000 & 2250000 & 2260000 & 2280000 & 2230000 & 2250000 & 2250000 \\
\hline
\end{tabular}


Hameed Al Qaheri is Associate Professor of Information Systems and Chairperson, of the Department of Quantitative Methods and Information Systems, College of Business Administration, Kuwait University. He has a Ph.D. in Information Sciences from the University of Pittsburgh. He has over 35 years of industry and academic experience. He leads several ICT-based business solutions for government agencies in Kuwait in the area of SocioEconomic Decision Support System and Simulation, Innovation Systems and Simulation, Optimization Projects, Business Process Management, Workflow Automation and Document Management Systems, ERP Systems, and eGovernment. His research interests span several areas including Intelligent Planning (national and corporate), Intelligent Human Augmentation Platform, Al-Based Arabic Text-Processing (Understanding, Categorization, Summarization, and Analytics), Intelligent Business Optimization, and Intelligent Digital Enterprise.

Mohamad K. Hasan is a Professor of Operations and Supply Chain Management at Dept. of Information Systems and Operations Management, College of Business Administration Kuwait University, Kuwait. He received a B.S. degree in Mathematical Statistics from Alexandria University, Egypt, in 1978. He received an M.S. degree in Mathematics in 1988 and a Ph.D. degree in Transportation Systems Analysis and Planning in 1991 both from Texas A\&M University, College Station, Texas, USA. His research interests include Logistics, Supply Chain Management, Network Optimization, Scheduling, Transportation Systems Analysis, Transportation Planning, Transportation Network Modeling, Freight Transportation Modeling, and Mathematical Programming. He presented his research at national and international conferences, including Transportation Research Board (TRB) Annual Meetings and INFORMS. His articles in Transportation Research Record, Networks and Spatial Economics, Telecommunication Systems, Journal of Transportation Engineering, International Journal of Operations Research and Information Systems, International Journal of Computer Information Systems and Industrial Management Applications, Engineering (Scientific Research), Journal of Service Science \& Management(Scientific Research), Informatica (An International Journal of Computing and Informatics), Proceeding of ASCE (American Society of Civil Engineering) Transportation Congress, San Diego, California, U.S.A.,), Proceeding of 1st CSCE (Canadian Society of Civil Engineering) Transportation Specialty Conference. Edmonton, Alberta, Canada, and Proceeding of 2nd CSCE (Canadian Society of Civil Engineering) Transportation Specialty Conference, Halifax, Nova Scotia, Canada.

Mohammad Zainal is an Associate Professor of Applied Statistics at the College of Business Administration, Kuwait University teaching Business Statistics and Computer Courses. He is also the current Acting Dean of the College, the Chair of the Board of Trustees at the Center of Excellence in Management, and the Associate Dean for Academic Affairs, Research \& Graduate Studies. Mohammad has published in the Journal of Economic Studies, Journal of Statistical Science and Application, Istanbul University Journal of the School of Business, Association for the Advancement of Modelling \& Simulation, International Journal of Thoracic and Cardiovascular Surgery, Asian Pacific Journal of Allergy \& Immunology, Journal of Clinical Immunology, and The International Academy of Business and Public Administration Disciplines. His research interests include Parametric Estimation in the SkewSymmetric Distributions, Optimization in High Dimensions, Goodness-of-Fit and Nonparametric Estimation, and the Application of Computer Methodologies to facilitate "Real-World" Solutions to Complex Business Problems. 